\title{
1815 Haritası'nda Antalya Kalesi: Surlar, Kapılar ve Burçlar
}

\author{
Evren Dayar*
}

\section{$\ddot{\mathbf{O} z}$}

Osmanlı döneminde Antalya Kalesi Anadolu'nun en önemli liman kaleleri arasında yer alıyordu. Önemi nedeniyle defalarca onarım görmüş, bu sayede 20. yüzyllın başlarına kadar ayakta kalmıştı. Antalya Kalesi'nin yaşadığı en kapsamlı onarımlardan biri 1812-1814 yılları arasında devam eden Tekelioğlu İsyanı'ndan sonra gerçekleşti. Tekelioğlu İbrahim Bey'in Sultan II. Mahmud'a isyan ettiği ve şehrin Osmanlı Devleti tarafindan kuşatıldığı bu dönemde kalenin birçok bölümü yıkılmıştı. Bu nedenle Antalya'nın ele geçirilmesinden sonra kalenin imarıyla ilgili ilk keşif heyeti şehre gelmiş, 1815 'te başlayan imar ve tamir süreci bir kaç yl devam etmişti. Ayrıca, imarı için 1825 ile 1836'da iki ayrı keşif raporu daha düzenlenen kale bu raporlar doğrultusunda da onarım görmüştür.

Tüm bu keşif raporları arasında en ayrıntılısı, Mimar Mustafa Raşid Efendi tarafindan hazırlanan 1815 raporudur. Raporda, Antalya Kalesi'nin bakıma muhtaç yerleri tek tek sıralanmıştır. Mustafa Raşid Efendi tarafindan çizilen ve raporla birlikte sunulan harita ise iç ve dış surları, kaleyi çevreleyen hendekleri, kale burçlarını ve kale kapılarını göstermektedir. Dolayısıyla, keşif raporundaki bilgiler ve harita sayesinde Antalya Kalesi’nin döneme ait yapısal bir panoramasını çıkarmak mümkün olmaktadır.

Bu çalışma, 1815 haritası olarak adlandırdığımız bu çizimin detaylı bir tanıtımını yapmayı amaçlamaktadır. Bu vesileyle 19. yüzyılın başlarında Antalya Kalesi’nin vaziyeti de tasvir edilmeye çalışlacaktır.

Anahtar Kelimeler: Antalya Kalesi, kent surları, burçlar, kapılar.

* Dr., Antalya/TÜRKIYE, evrendayar@gmail.com. ORCID: 0000-0002-6593-7238 DOI:

Makale Gönderim Tarihi: 18.10.2018 - Makale Kabul Tarihi: 09.01.2020

Belleten, Ağustos 2020, Gilt: 84/Sayı: 300; 667-716 
Antalya Castle on the 1815 Map: City Walls, Doors and Towers

\begin{abstract}
During the Ottoman Empire period, Antalya Castle was one of the most important port castles of Anatolia. It has been repaired many times due to its importance, and thus it has managed to remain standing until the beginning of the $20^{\text {th }}$ century. One of the most extensive repairs of the Antalya Castle occurred after the Tekelioğlu Rebellion, which continued between the years of 1812-1814. During this period, when Ibrahim Bey rebelled against the Sultan Mahmud II and the city was besieged by the Ottoman Empire, many parts of the castle were ruined. Therefore, after the seizure of Antalya, the first repair teams came to the city and the reconstruction process which was going to continue for several years, started in 1815. In addition, during this period, for the repair of Antalya Castle, two different discovery reports were prepared in 1825 and 1836, and Antalya Castle has been repaired in accordance with these reports.

The most detailed of all these discovery reports is the 1815 report prepared by the Architect Mustafa Raşid Efendi. In the report, the need for repair of Antalya Castle was written in detail. The map drawn by Mustafa Raşid Efendi shows the interior and exterior walls, the ditches surrounding the castle, the castle towers and the castle gates. Thus, it is possible to extract a structural panorama of Antalya Castle in the early $19^{\text {th }}$ century thanks to the information in the discovery report and the map.

This article aims to come up with a detailed description of the drawing that we called the 1815 Map. On this occasion, the condition of Antalya Castle in the beginning of the $19^{\text {th }}$ century will be tried to be depicted.
\end{abstract}

Keywords: Antalya Castle, city walls, towers, doors.

\title{
Giriş
}

Antalya Kalesi'ni tasvir eden günümüze ulaşmış en önemli görsel belgelerden biri, 1812-1814 arasında devam eden Tekelioğlu İsyanı'nın bastırılmasından sonra Hassa Mimarı Mustafa Raşid Efendi tarafından çizildi. Kalenin kuşbakışı bir tasviri olan bu harita esasında bir keşif defterinin ekiydi ve isyan nedeniyle tahrip olan kalenin tamire muhtaç bölümleri hakkında Babıâli'yi bilgilendirmek ve gerekli izinleri almak amacıyla hazırlanmıştı. Tekelioğlu İbrahim Bey'in Sultan II. Mahmud'a başkaldırdığı ve şehrin Osmanlı Devleti tarafindan kuşatıldığı isyan senelerinde kale ciddi bir tahribata uğramış, bu nedenle Antalya'nın ele geçirilme- 
sinden sonra şehre bir heyet gelerek imar ve tamir keşif sürecini başlatmışt. ${ }^{1}$ Ayrıca, 19. yüzyllın ilk yarısında kalenin tamiri hususunda ilki 1825'e diğeri 1836'ya tarihlenen iki ayrı keşif defteri daha düzenlenmiş ve Antalya şer'iyye sicillerine işlenmişti. ${ }^{2}$

Bu keşif defterleri arasında en ayrıntılısı Hassa Mimarı Mustafa Raşid Efendi tarafından hazırlanan 1815 tarihli defterdir. Defterde kalenin bakıma muhtaç yerleri tek tek sıralanmış, onarım faaliyeti esnasında kullanılacak demir, taş, kiremit, kereste, kum, kireç vb. malzemelerin çeşit ve miktarı, çalıştırılacak usta ve iş̧̧i sayısı, bunların günlük ücretleri hakkında bilgilere yer verilmiştir. ${ }^{3}$ Deftere eşlik eden ve kalenin tahrip olan bölümleri hakkında bilgi vermek amacıyla göz kararı çizilen haritada ise kaleyi çevreleyen hendekler, iç ve diş sur duvarları, kale burçları ve kapıları ile kalenin müstahkem mevkileri gösterilmiştir. Dolayısıyla, keşif defterindeki bilgiler - defterin belgesel değerini daha da arttıran- haritayla birlikte ele alındığında Antalya Kalesi’nin döneme ait bir panoramasını çıkarmak mümkün olmaktadır. Zira harita, kapı ve burçların yerleri ile kalenin taksimatını bu hususta spekülasyon yapmayı gerektirmeyecek kadar açık göstermektedir. Bu makalede, Mustafa Raşid Efendi'nin keşif defterini ve haritasını kullanarak Antalya Kalesi’nin 19. yüzyıl başlarındaki vaziyetinin bütüncül bir panoramasını çıkarmaya çalışacağım. Çalışmada inşaat faaliyetinin tüm tafsilatına değinilmeyecek, keşif defteri esas olarak haritayı anlamlandırmak ve kalenin ana unsurlarını ortaya çıkarmak için kullanılacaktır.

1 Tekelioğlu İsyanı hakkında bkz. Fahrettin Tızlak, "Tekelioğlu İsyanı", XIII. Tarih Kongresi (4-8 Ekim), c. III, Ankara 2002, ss. 237-254. Keşif defterinden anlaşıldığı kadarıyla sadece savaş koşulları değil, firtına (mahall-i mezkûr bârândan muhâfaza olunamayub) veya deniz dalgaları (telâtum-ı deryâ darbryla münhedim olmağla) gibi doğal nedenler de kalenin tahribine neden olmuştur. Bkz. BOA. C. AS. 840-35837, lef. 6/117, 118.

2 1825'e tarihlenen rapor 3 numaralı sicile kaydedilmiştir. Esasında 3 numaralı sicilde iki keşif defterine rastlanır. "Antalya Kal'asinn I'mân Lâzzm Mahallerinin Mukarrerât Defteri" olan ilk keşif defteri Ekim 1825 tarihlidir ve Hassa Mimarı Abdülkadir tarafindan hazırlanmıştır. Hassa Mimarı Ahmed Derviş Efendi marifetiyle hazırlanan ve 10 Haziran 1827’ye tarihlenen diğer keşif defteri ise 1825 'te belirtilen tamiratın denetimi (tầmîr ve inşấ' edilen mahallin yegân yegân muâyenesi) mahiyetindedir. Her iki rapor için bkz. AŞS. 3/1, 124.

1836 tarihli rapor ise Mehmed Raşid Efendi ve Süleyman Efendi tarafindan hazırlanmış, 7 Mart 1836'da 6 numaralı sicile kaydedilmiştir. Bu rapor, esas olarak kale dışındaki hendeğin ve tabyaların keşif ve inşasıyla; ayrıca iç kalenin onarımıyla ilgilidir. Bkz. AŞS. 6/65-77.

3 Rıfat Özdemir, "Osmanlı Döneminde Antalya’nın Fiziki ve Demografik Yapısı (1800-1867)”, XI. Türk Tarih Kongresi (5-9 Eylül), c. IV, Ankara 1994, s. 139. 


\section{1. İmar ve Tamir Keşif Kayıtları}

Osmanlı döneminde önemli yapıların imar ve tamiri başkentin denetimi altında yürütülüyordu. İmparatorluğun başkentten uzak bölgelerinde bu tür faaliyetlerin gerçekleştirilmesi amacıyla ilk olarak merkezden o bölgeye bir mimar gönderiliyor, bu mimarın başkanlığında yerel yetkililerin de aralarında olduğu bir keşif heyeti oluşturuluyordu. Mimarın görevi, uygun bir keşif defteri hazırlamak ve bunu tahmini maliyetiyle birlikte başkente göndermekti. Ayrıca, İstanbul'a gönderilen bu raporlar mahallindeki şer’iyye siciline kaydediliyordu. ${ }^{4}$

Başkente gönderilen raporların onay alması büyük ölçüde onarım işinin maliyetine bağlıydı. Bu nedenle, talep edilen onay kararı için işin tahmini maliyetinin önceden hesaplanması gerekiyordu. Maliyet tahmini için başvurulan keşif usulünde, yapılacak tüm imalatlar keşif heyeti tarafindan yerinde tespit ediliyor, işçilik ve malzeme miktarları kalem kalem çıkartılıyor, bunlar piyasada geçerli olan fiyatlarıyla değerlendirilerek onarımın yaklaşık maliyeti elde ediliyordu. Neticede, yaklaşık maliyeti de içeren keşif defteri imar ve tamir çalışmasına onay almak için başkente gönderiliyordu. Maliyeti önceden bilinmeyen çalışmalara izin verilmiyordu. ${ }^{5}$

Şer'iyye sicillerinde bu şekilde hazırlanmış keşif defterlerine rastlamak mümkündür. Antalya Kalesi'nin tamirine ilişkin hazırlanan ve bu çalışmaya esas teşkil eden ilk defter ise 1 numaralı sicile kaydedilen "Kal'a-ı Hâkâni'den Antalya Kal'asının Ta'mîr ve I'mârna Dair Keşif Kaydı"dır.

İsyanın bastırılması akabinde, 1814 sonları veya 1815 başlarında Antalya’ya gelen Hassa Mimarı Mustafa Raşid Efendi tarafindan hazırlanan ve işin maliyetini de gösteren keşif defterlerinden ilki şer’iyye siciline işlenmiş; ekine Antalya Kalesi'ne ait haritanın iliştirildiği diğeri ise İstanbul'a gönderilmiştir. İstanbul'da işin önemi ve 160.578 kuruşa tekabül eden maliyeti tetkik edildikten sonra kalenin "metin ve müstahkem olarak seri'an inşâ ve itmâmı için" ferman sadır olmuştur. ${ }^{6}$

Keşif defterlerinden şer’iyye siciline kaydedileni iki bölümden oluşur. İlki 25 Nisan

4 Özdemir, a.g.m. ss. 142-143.

5 İbrahim Yılmaz; Ümit Dikmen, “Osmanlı Döneminde Kullanılan Yaklaşık Maliyet Tahmin Yöntemleri”, New World Sciences Academy, c. 7, no. 1, 2012, ss. 74-77.

6 İstanbul'a gönderilen defterle birlikte başkentten duvarcı, taşçı ve kemerci de talep edilmiştir. Ancak bu dönemde Tuna sahilinde inşa edilen kale için Istanbul'dan çok sayıda amele görevlendirildiğinden Antalya ve çevresinden amele bulması istenmişti. Bkz. AŞS. 1/23, 24. 
1815 tarihlidir ve girişinde keşif işlemi ile işin mahiyeti hakkında bilgi verilmiş̧ir. Daha sonra, madde madde kalenin hangi bölümlerinin nasıl bir tamire ihtiyaç duyduğu anlatılmıştır. Defterin ilk kısmını oluşturan bu bölümde dış surlarda gerçekleştirilecek tamirata ilişkin bilgi verilmiştir. ${ }^{7}$ Defterin ikinci bölümü ise 8 Mayıs 1815 'te sicile geçirilmiştir. Bu bölüm önceki defterin devamıdır ve burada esas olarak perde surlarda yapılacak tamirata değinilmiştir. ${ }^{8}$

İstanbul'a gönderilen ve bu makalede kullanılan defter ise birkaç istisna haricinde sicile kaydedilenle aynıdır. Bu istisnalardan ilki, başkente gönderilen defterde her keşif kaleminin altında ilgili tamiratın maliyetinin de olmasıdır. Sicile kaydedilen defterde ise maliyet hesabı yapılmamıştır. Bunun dışında, İstanbul'a gönderilen defterin 18, 19, 20, 21, 33, 34, 35, 36, 37, 38 ve 95 numaralı tamirat kalemleri şer’iyye sicilindeki defterde yoktur. Sicildeki 18 numaralı tamirat kalemi de İstanbul'a gönderilen defterde yer almamaktadır. Bunların dışında, her iki defter arasındaki esas fark, başkente gönderilene bir haritanın eşlik etmesidir. Harita üzerinde, kalenin genel bir görünümünün yanı sıra tamire muhtaç bölümleri numaralandırılarak gösterilmiştir. Ayrıca, haritada kullanılan her numaranın karşılığı başkente gönderilen defterde yer almaktadır. ${ }^{9}$ Başka bir ifadeyle, mimar, kalenin hangi bölümlerinin tamire muhtaç olduğunu harita aracıllğıyla "ism u resm-i ş̋̈hretleriyle kayd" etmiş, ilgilileri için tarif etmiştir. ${ }^{10}$

\section{Keşif Defterinin İçeriği ve Defterde Kale Mimarisine İlişkin Geçen Kavramlar}

Mustafa Raşid Efendi İstanbul'a gönderdiği keşif defterinde, saptadığı tahribatı ve müdahale önerilerini 123 kalemde anlatmış; önerdiği müdahalelerin alanını-ilgili yapının enini arzan, boyunu tûlan, yüksekliğini kadden, çevresini devren kaydederekhesaplamış, uzunluk ölçüsü olarak zirâ' kullanmıştı.

Defterin ilk 94 kalemi, esas olarak, kuşatmada en ağır tahribatı almış dış sur duvarlarının; duvar siperlerinin, dendânların ve bunların üzerindeki harpüştelerin; seğirdim teraslarının; burçların ve burçlara ait çatıların; kale kapılarının tamiri veya tekrar inşasıyla ilgilidir. Defterin 94. kalemden sonra başlayan ikinci bölümü

7 AŞS. $1 / 87$.

8 AŞS. 1/92.

9 Harita üzerindeki tanımlı yapılar ile keşif defterinde tarif edilen yapıları ekte sunduğum haritalarda, ilkini siyah, ikincisini ise kırmızı renkle yazarak göstermeye çalıştım.

10 BOA. C. AS. 840-35837, lef. 6. 
perde sur ile limanda deniz içinde kalan duvarlarla ilgilidir. Zira rapordan da anlaşıldığı üzere, perde sur ve gerisindeki toprak şerit de tahrip olmuştur. Defterin son maddesi ise kalenin içindeki ve dışındaki top döşemelerinin yenilenmesini talep etmektedir. ${ }^{11}$

Tahrip olan sur duvarlarının tamiri için defterde "derz-i tecdîd ile kal'a dî̀âir tamiri", yıkılan bölümlerin yapımı için "cedîd taşla kum ve kirec ile memzûc harcla yüzleme dî̀âr inşası" ifadeleri kullanılmıştır. ${ }^{12}$ Bunların dışında, onarım faaliyetleri kapsamında; burçlardaki pencere ve harpüştelerin tamiri, çatılı burçların kiremitlerinin aktarılması ve çatılarının yenilenmesi, burçların içindeki demir korkuluk ve parmaklıkların inşası, yıkılan kapıların yeniden yapımı, siper ve hisar-peçelerin yenilenmesi, kaleye çıkan merdivenlerin yenilenmesi, seğirdim teraslarının tamiri gibi işler de yapılmıştır. ${ }^{13} \mathrm{Bu}$ işlemler için cedid taş, atîk taş, hâlis harc, kum ve kireç ile memzuc harc kullanılmıştır. Öte yandan, keşif defterindeki ifadelerden her zaman yeni malzeme kullanılmadığı, enkazdan da (bazı enkazyyla mahlûtan tecdidi) faydalanıldığı anlaşımaktadır. ${ }^{14}$

Keşif defteri, kalenin muhtelif yapı ve unsurlarını kendi içinde tutarlı olacak şekilde tanımlamıştır. Örneğin, "kale bedeni" de denilen ve esas müdafaa hattını oluşturan dış sur duvarı defterde kal'a dîwâri olarak adlandırılmıştır. ${ }^{15}$ Sur dibine yaklaşan düşmanı vurmak için duvarlara bitişik ve harice taşkın şekilde inşa edilen yuvarlak ya da köşeli kuleleri tanımlamak için kullanılan ifade ise günümüzde olduğu gibi burçtur.

11 BOA. C. AS. 840-35837, lef. 6/123. Gerek keşif defterindeki ifadelerden gerekse harita üzerindeki yazılardan kalenin bazı bölümlerinin defterin hazırlanmasından ve haritanın çizilmesinden önce -muhtemelen kuşatmadan kısa bir süre sonra- tamir edildiği anlaşılmaktadır. Bu durum defterde "mukaddem tamir olunmuş olub" ifadesiyle anlatılmış, haritada da ilgili yerlere "tamir olunmuş" notu düşülmüştür. Bazı örnekler için bkz. BOA. C. AS. 840-35837, lef. 3/56; lef 4/58.

12 BOA. C. AS. 840-35837, lef. 2/1, 2. Bu ifadeden, sur duvarlarının inşasında kullanılan harcın kireç ve kum karıştırılarak elde edildiği anlaşılmaktadır. "Horasan” adıyla da bilinen bu harç tekniği Osmanlılar tarafından kale duvarlarını berkitme yöntemi olarak sıklıkla kullanılmıştır. Bu yöntem surların çok daha güçlü ve top ateşine dayanıklı olmasını sağlıyordu. Bkz. Mark L. Stein, Osmanlı Kaleleri Avrupa'da Hudut Boylan, çev. Gül Çă̆alı Güven, İş Bankası Yayınları, İstanbul 2007, s. 46.

13 Bu çalışmada keşif defterinde 124 iş kalemi altında ayrıntılı biçimde tarif edilen tamir ve inşa faaliyetine ilişkin genel bazı örnekler vermekle yetindim. Perde duvarların ve dış surların büyük ölçüde tahrip olduğu, pek çok burcun ve kapının yıkıldığı bir kuşatmadan sonra yapılacak onarım faaliyetinin çok kapsamlı olacağı aşikârdır. Dolayısıyla, keşif defterinin, tamir ve inşa faaliyetinin tüm ayrıntıları açısından değerlendirilmesi ancak başka bir makalenin konusu olabilir.

BOA. C. AS. 840-35837, lef. 1/14; lef. 3/52; lef. 4/67; lef. 5/88, lef. 5/94.

Örnekler için bkz. BOA. C. AS. 840-35837, lef. 1/1, 3, 4, 6.

Belleten, Ağustos 2020, Cilt: 84/Sayı: 300; 667-716 
Kale mimarisinde, sur duvarının üstünde müdafilerin hareket edebilmelerini sağlamak amacıyla yapılan düz yol anlamına gelen seğirdim terası ${ }^{16}{ }^{\text {keşif defterinde }}$ de aynı anlama gelecek şekilde kullanılmışır. ${ }^{17}$ Tahrip olan seğirdim teraslarıyla ilgili kullanılan tarifler, bunların nerede olduklarını ve işlevlerini ortaya koymaktadır: "Kal'a dî̀ârmnn derûnî tarafi münhedim olub piyade seğirdimi mahallinden mürur olunmamağla" ${ }^{18}$ veya "kal'anm derûnî tarafinda münhedim olan dîvâri sebebiyle seğirdiminden mürur olunmamağla." ${ }^{19}$ Defterde seğirdim mahalli olarak adlandırılan bir başka yer ise dışsur duvarı ile perde sur arasında kalan toprak şerittir. ${ }^{20}$

Kale mimarisinde "hisar-peçe" veya "gömlek sur" adiyla tesmiye olunan, ${ }^{21}$ dış surları çepeçevre kuşatan daha alçak duvarları tanımlamak için keşif defterinde "perde sur" (hârici estâr dîvâri) kavramı kullanılmıştır. ${ }^{22}$ Genellikle "mazgal siperi" olarak adlandırılan, ${ }^{23}$ sur duvarının veya burçların üstünde yer alan ve dışarıdan gelecek saldırılara karşı piyadelerin korunabilmesi için insan boyundan biraz daha yüksek inşa edilen duvar siper veya siper dîvârî olarak tanımlanmıştır. ${ }^{24}$

Keşif defterinde geçen bazı kavramlar ise günümüzde onlara atfedilmiş anlamlaryyla kullanılmamıştır. Örneğin, siper duvarı üzerinde bulunan ve kale mimarisinde "dendân" veya "barbata" olarak adlandırılan diş şeklindeki yapılara defterde hisar-peçe (bazen sadece peçe) denilmiş, yağışın etkisinden korumak için bu yapıların üzerlerinde, bir tarafa ya da ortadan iki tarafa eğimli kaplamaların (harpüsste) bulunduğu ifade edilmiştir. ${ }^{25}$

16 Celal Esad Arseven, "Kale”, Sanat Ansiklopedisi, c. II, Milli Eğitim Basımevi, İstanbul 1983, s. 908.

17 Bazı örnekler için bkz. BOA. C. AS. 840-35837, lef. 4/62, 73, 80.

18 BOA. C. AS. 840-35837, lef. 4/62.

19 BOA. C. AS. 840-35837, lef. 4/73.

20 Bazı örnekler için bkz. BOA. C. AS. 840-35837, lef. 5/106, 109.

21 Kale mimarisinde "hisar-peçe", bir kale veya hisarı ya da bir kapı veya köprüyü müdafaa etmek üzere onun ilerisine yapılan mazgal delikli ve siperli sur ve kule anlamında kullanılmaktadır. Bkz. Arseven, a.g.e., s. 909.

22 BOA. C. AS. 840-35837, lef. 2/106.

23 Arseven, a.g.e., s. 908.

24 Keşif defterinde geçen siper dîvâri ifadesi için bkz. BOA. C. AS. 840-35837, lef 4/77.

25 Keşif defterinde birçok defa burçlara ait siper ve hisar-peçeler ile burçların etrafindaki hisarpeçelerin harpüştelerinden bahsedilmiştir. Bazı örnekler için bkz. BOA. C. AS. 840-35837, lef. 2/19, 21, 33; lef. 4/59, 65, 71; lef. 5/99, 100, 101, 106, 107. Bir örnekte ise sadece "peçe" ifadesi kullanılmış, burcun peçesinin harap olduğu belirtilmiştir. Bkz. BOA. C. AS. 840-35837, lef. 4/75. 


\section{1815 Haritası'nda Antalya Kalesi'nin Görünümü, Hendekleri, Perde Surlar ve Diş Surlar}

Antalya, verimli ve tarımsal açıdan zengin bir ovanın kenarında, Anadolu'nun iç bölgelerine giden kara yolunun kavşağında ve Akdeniz'e açılan doğal bir limanın üzerinde konumlanır. Şehrin kuruluşunda ve gelişiminde bu konumu, daha sonra korunaklı bir limana dönüşecek küçük bir deniz girintisinin varlığı ve denize kolay ulaşabilme özelliği rol oynamıştır. Limanın merkezde olduğu ilk yerleşim, muhtemelen, kurulduğu dönemde bir savunma sistemine sahipti. M.Ö. 2. yüzyılda "Attaleia" olarak şehirleşmesiyle birlikte bu ilk yerleşim büyük bir fiziki değişime uğramış, günümüzde bilinen sur duvarlarının çevrelediği alana yayılmıştı. ${ }^{26}$

Şehri kuşatan surlar 20. yüzyılın başlarına kadar ayakta kalmıştır. Bu durum, en sonuncusu 19. yüzyllın ilk yarısına tarihlenen ve sürekli yenilenen tamiratlar nedeniyledir. Babıâli'nin Avrupa'daki gibi surları yıkmaya yönelik ilk girişimleri ise 1870'lere tarihlenir. Fakat bu girişimler sürekli ertelenmiş, 1914'teki ilk kapsamlı yıkım, surların şehri havasız bırakarak sağlığı tehdit ettiği gerekçesine dayandırılmıştır. Yıkım, Ali Paşa Sarayı'nın bulunduğu bölüm ve çevresinde başlatılmıştı.. ${ }^{27}$

Antalya surları, Osmanlı İmparatorluğu'ndaki önemli savunma yapıları arasında yer alıyor ve batıdan doğuya doğru bir at nalı biçiminde geniş bir kavis çizerek şehri kuşatıyordu. Sur önünde perde sur, onun ilerisinde ise ön savunma hattını oluşturan hendek bulunuyordu. 1815 haritasında göze çarpan ilk husus şehrin istihkâmını güçlendirmek için Roma döneminde kazıldığı düşünülen, ${ }^{28} 17$. yüzyılın ikinci yarısında şehre gelen Evliya Çelebi'nin "yirmi arşın derinlikte, yirmi arşın eninde, kesme kaya hendek" olarak tanımladığı bu hendeklerdir. ${ }^{29}$ Topun

26 Burhan Varkıvanç, "Surların Oluşum Süreci Üzerine Bazı Gözlemler", Redford, Scott; Leiser, Gary, Taşa Yazılan Zafer Antalya İçkale Surlarndaki Selçuklu Fetihnamesi içinde, çev. İnci Türkoğlu, Suna-İnan Kıraç Akdeniz Medeniyetleri Araştırma Enstitüsü Yayınları, İstanbul 2008, ss. 57-58.

27 H. Hellenkemper; F. Hild, "Lykien und Pamphylien", Tabula Imperi Byzantini, 8 (2004), s. 320. Haziran 1919'da Kebîr Kapr (Kale Kapısı) ile 19. yüzyllın ikinci yarısından itibaren ekseriyetle "Tophane" adıyla anılmaya başlanan Ali Pașa Sarayı'nın bulunduğu alan arasındaki duvarlar yıkılmış bulunuyordu. Ancak kale bedenlerinin enkazı hala yerli yerindeydi ve hem bu enkazın hem de açığa çıkana arazinin (otel, gazino ve park inşası amacıyla) değerlendirilmesi için yerel belediye bazı girişimlerde bulunmuştu. Bkz. BOA. DH. UMVM. 97-38.

28 Leyla Yılmaz-Kemal Tuzcu, Antalya’da Türk Dönemi Kitabeleri, Haarlem 2010, s. 21; Aşkıdil Akarca, Şehir ve Savunmast, Türk Tarih Kurumu Basımevi, Ankara 1998, s. 175.

29 Evliya Çelebi, Günümüz Türkçesiyle Evliyâ Çelebi Seyahatnamesi: Kütahya, Manisa, İzmir, Antalya, Karaman, Adana, Halep, Şam, Kudüs, Mekke, Medine, c. I, haz. Seyit Ali Kahraman, Yapı Kredi Yayınları, İstanbul 2011, s. 310. 
yaygın bir kullanım alanı bulduğu 15. yüzyıla kadar kaleleri bir hendekle -ve perde surla- ihata etmek, muhacimlerin sur duvarlarını aşıp şehre girmelerini sağlayan kuşatma merdivenlerine ve şahmerdanlara karşı alınabilecek en güçlü tedbirdi. ${ }^{30}$ Bu sebeple Antalya Kalesi, on iki adım genişliğinde, muhtemel bir tehlikeye karşı içi suyla doldurulan derin bir hendekle çevrelenmişti. ${ }^{31}$

1815 haritasının en batısında, kaleyi çevreleyen hendeklerin ötesinde -Kadınyarı'nın olduğu tarafta- yer alan başka bir hendek daha çizilmiş̧ir. Bu hendek, herhalde Düden'in kolu olan nehirdi (Kadın Deresi) ve şehrin savunmasında doğal bir engel işlevi görüyordu. Bu doğal engel, muhtemelen 1812-1814 kuşatmasında derinleştirilmiş, şehri çepeçevre muhafaza etmesi için tahkim edilmiştir. Haritada da belirtildiği gibi hendek işlevi gören nehrin şehre bakan doğu tarafı bir duvarla güçlendirilmişti. Haritada bu duvarın çizildiği alanın içine seğirdim dî̀ârî ifadesi düşülmüş̧ür. Tüm bu hususlar şehrin harici savunma hattını göstermesi açısından önemlidir.

Kuşatma döneminde esas çatışmaların yaşandığı şehrin varoşu, Düden'in oluşturduğu bu doğal hendek ile Antalya Kalesi arasındaki geniş sahada yer almıştır. ${ }^{32} \mathrm{Te}-$ kelioğlu İbrahim Bey, "120 kıt'a kâgir kule" ile donattığı ve şarampoller kazdırdığı bu bölgeyi kale savunmasının bir parçası olarak görmüştür. ${ }^{33}$ Zaten 19. yüzyılın başlarında bu bölge İbrahim Bey’in buradaki konağına (Mesellim Konağı) atıfla "Varoş Kalesi" olarak isimlendirilmiştir. ${ }^{34}$ 19. yüzyılın ikinci yarısına gelindiğinde bu bölümün tamamen yerleşime açıldığı düşünüldüğünde, isyanın bastırılmasından sonra buradaki şarampollerin doldurulmuş, "tabya" adı da verilen kulelerin ise yıkılmış veya yıktırılmış olması ihtimal dâhilindedir. ${ }^{35}$ Yerleşime açılma süreci 1821 Mora İsyanı’ndan sonra şehre gelen göçmenlerin bir kısmının "şarampol ve

30 Matthew Bennett; Jim Bradbury vd., Dünya Savaş Tarihi Ortaçă̆, Teçhizat-Savaş-Yöntemleri- Taktikler 500-1500, c. 1, çev. Özgür Kolçak, Timaş Yayınları, İstanbul 2011, ss. 196, 201.

31 Hellenkemper; Hild, a.g.e., s. 324.

32 Bu varoş bölgesi bazı belgelerde "sevad-ı belde" olarak adlandırılmıştır. Bkz. BOA. C. DH. 763780.

33 BOA. HAT. 1224-47843; BOA. HAT. 1224-47851.

34 BOA. HAT. 1224-47828.

35 1830'ların ortalarında şehrin istihkâmını kuvvetlendirmek için bu muhite ve kalenin hemen dışında yer alan kara tarafindaki sekiz noktaya tabya inşa edilmesi için girişimlerde bulunulduğu göz önüne alınırsa, Tekelioğullarına ait "tabyaların" isyanın bastırılmasının akabinde veya bir süre sonra yıkıldığı ya da yıktırıldığı düşünülebilir. Her ne kadar yüksek maliyeti nedeniyle gerçekleşmemiş bir tasarı olarak kalsa da, 1835-36'da Antalya Kalesi'nin varoşunda inşa edilmesi tasarlanan tabyalar için bkz. BOA. D. BŞM. BNE. d. 16431, lef. 8. 
çevresindeki saz damlara" iskânıyla başlamış, ${ }^{36}$ Teşvikiye Mahallesi’nin kurulmasıyla nihai halini almış olmalıdır. ${ }^{37} 20$. yüzyıla gelindiğinde ise geçmişte burada bulunan şarampol ve savunma kulelerinden geriye bir mahallenin adı (Şarampol Mahallesi) yadigâr kalmıştır.

1815 haritası, şehri bir miğfer gibi çevreleyen ve esas müdafaa hattını oluşturan dış surların tümünün, Bizans döneminde yapıldığı iddia edilen alçak bir perde surla kuşatıldığını da gösterir. ${ }^{38}$ Haritada siyah kesik çizgilerle gösterilen ve keşif defterinde hârici estâr dî̀âri (hisar-peçe) adıyla tanımlanmış bu dişli (dendân) duvar, keşif defterinden anlaşıldığı kadarıyla ortalama 3,5 zirâ' (2,5 metreden fazla) yüksekliğinde idi ve yedi adım kadar ardında yer alan kendisinden daha yüksek dış sur duvarı tarafindan etkin biçimde korunabiliyordu. Kale mimarisi açısından perde surların esas işlevi hendekleri müdafaa etmekti. ${ }^{39}$

Harita, kale burçlarını birbirine bağlayan ve yüksekliği topografyaya göre değişen dış surları da gösterir. ${ }^{40}$ Keşif defterinde ifade edildiği üzere bu duvarların üzerinde seğirdim terası adı verilen devriye yolu yer alır. Antalya Kalesi’nin seğirdimleri, esas sur duvarının üzerine inşa edilmiş siper ve dendânlarından oluşturulmuştur. Duvarların üzerinde piyade trafiğine imkân veren bu terasa merdivenler aracılığıyla çıkılmaktadır ki, defterde merdivenlerin varlığı "kal'aya 'urûc edecek nerd-bân" ifadesiyle anlatılmıştır. ${ }^{41}$ Haritada ise sadece kuşatma esnasında tahrip olmuş merdivenler resmedilmiştir.

Burada son olarak, haritada perde surların üzerinde siyah kesik, dış sur duvarlarının üzerinde ise kırmızı kesik çizgilerle gösterilen dendânların sayısal bir karşılı̆̆ı olmadığını; keşif defterinde dendânlara ve onların üzerindeki harpüştelere, yaşa-

36 AŞS. 19/388b.

37 BOA. İ. ŞD. 1702-23.

38 Leyla Yılmaz, Antalya (16. Yüznlln Sonuna Kadar), Türk Tarih Kurumu Yayınları, Ankara 2002, s. 107. Öte yandan, hendek, perde sur ve dış surdan oluşan bu tahkimat sisteminin ne kadar eski olduğu hususunda kesin bir tahminde bulunmak güçtür. Perde surlar ise 10. yüzyıldaki Arap akınları döneminde tahkim edilmiştir. Bkz. Hellenkemper; Hild, a.g.e., s. 325.

39 Arseven, a.g.e., s. 909.

40 E. Sperling, "Ein Ausflug in die Isaurischen Berge im Herbst 1862", Zeitschrift für Allgemeine Erdkunde, c. 16, Berlin 1864, s. 67. Surların yüksekliği hakkında keşif defterinde verilen rakamlara göre dış sur duvarlarının yüksekliği genel olarak 12 ila 18 zirâ' (9 ila 14 metre kadar) arasında değişmektedir. Ali Paşa Sarayı'nı çevreleyen bölümde ise duvar yüksekliği 14 metreye kadar çıkmaktadır. Dış surların en alçak olduğu bölüm, ortalama 9 metre yükseklikle Mermerli Köşk ile Hidırlı Burcu arasında kalan falezlerin üstündeki sur hattıdır. 
dıkları tahribat nedeniyle "hisarpeçe ve harpüşteleri bazı tecdîd ve tamiri" ifadesiyle atıf yapıldığını ifade etmek gerekir. ${ }^{42}$

\section{1815 Haritası'nda Kale Kapıları}

Mustafa Raşid Efendi’nin haritasında liman ve çevresi hariç dış surların içinde kalan şehir, birbirinden ayrı altı bölüm halinde resmedilmiştir. Dış surlar ile perde surlar arasında yer alan toprak şerit ise beş bölüme ayrılmıştır. Tüm bu bölümler arasında geçiş ve irtibat haritada da gösterilen kapılar aracılığıyla sağlanmaktadır.

Kale mimarisinde kapı, en basit haliyle, sur duvarlarına açılmış geçitlerdir. Bu geçitler vasıtasıyla kaleler dış dünyaya açılır; ancak kapılar en çok kalelerin farklı bölümleri arasındaki irtibatı sağlar. 17. yüzyılın ikinci yarısında Evliya Çelebi, Antalya Kalesi’nde birçoğu mahalleler arasında yer alan, bazısı geceleri kapanan, bazısı kapanmayan yirmi iki kapı olduğunu yazmıştır. ${ }^{43}$ Corneille Le Bruyen ise sadece kalenin dışarıya açılan kapılarına değinmiş, şehrin biri limanda diğeri kara tarafinda olmak üzere iki kapısı olduğunu söylemiştir. ${ }^{44}$

1815 haritasında Antalya Kalesi'nin muhtelif bölümlerinde yer alan -bazen tek bir mevkide iki veya daha fazla sayıda olmak üzere- otuz bir kapı gösterilmiştir. Haritadan anlaşıldığı kadarıyla, Mehmed Paşa Câmi karşısındaki burçtaki iki kapı açıktır. Kırmızı çerçeveli resmedilmiş kapıların ahşap, siyah çerçeveli olanların ise "poterna" olarak tanımlanan, tehlike anında örülerek battal hale getirilebilen küçük kapılar olduğu düşünülebilir. ${ }^{45} \mathrm{Bu}$ tip kapıların tamamı perde surların üzerinde ya da arasındaki duvarlarda yer almaktadır.

Poterna tipi kapıların sadece iç sur duvarları üzerinde değil, perde surların üzerinde de bulunması, bu kapıların esas işlevinin -Ortadoğu şehirlerinde mahalleler arasındaki etnik bölünmeyi yansıtan ve iç güvenliği sağlamak amacıyla yapılmış mahalle kapılarının aksine- harici saldırganları engellemek olduğunu düşündürtmektedir.

42 Bazı örnekler için bkz. BOA. C. AS. 840-35837, lef. 1/4, 5, 6, 8.

43 Evliya Çelebi, a.g.e., s. 311.

44 Corneille Le Bruyn, Vyage au Levant, L'Asie Mineure, Chio, Rhodes, Chypre, E'c. D'Egypte, Syrie, E̊ TerreSainte, c. 2, Paris 1725, s. 522.

45 Semavi Eyice, "Kale", TDV Íslam Ansiklopedisi, c. 24, Türkiye Diyanet Vakfi Yayınları, İstanbul 2001, s. 235. 


\section{a. Perde Surlar Üzerindeki Kapılar}

Haritanın çizildiği tarihte Antalya Kalesi'nin perde surları üzerinde üç farklı noktada, biri kapalı beş kapı vardır. İlk iki kapı, Kaleiçi'nden "varoşa" çıkışı sağlayan yegâne kapı olan ve günümüzde Saat Kulesi olarak işlev gören burcun bitişiğindeki Kebîr Kapı'nın (Kale Kapısı) karşısındadır. Burada perde sur üzerinde yer alan ve keşif defterinde Kapı Burcu olarak tanımlanan bir burç göze çarpar. Bu burcun içinde iki kapı (burc-ı mezkûrun dâhili ve hâricinde olan iki aded kapu) vardır (Ek 1-A2, A3) ${ }^{46} \mathrm{Bu}$ kapılardan çıkınca hendek üzerindeki dolgu alandan geçilir ve hendeğin çarşı tarafinda yer alan bir diğer kapıdan (burc-ı mezkûr verâsı ittisali hendek dî̀âri beyninde çarşu tarafinda olan ahşap kapu) çarşıya çıkılır (Ek 1-A1) ${ }^{47}$ Bu mevkide kapı sayısının bu denli arttırılması ve kapıların burçların içine konumlandırılmasının nedeni ise kaleye girişlerin sıkı bir şekilde kontrol altına alınmak istenmesidir. Evliya Çelebi de, bu güvenlik endişesiyle ilişkili olsa gerek, şehrin "varoşa" açılan kapılarının ardında Dizdar Divanhanesi ve mescidi olduğunu, bütün neferlerin bu mahalde "pür-silah hazır" bulunduğunu yazmıştır. ${ }^{48}$

Perde surlar üzerindeki diğer kapı, Baruthane Burcu'nun karşısında yer alan Seğirdim Duvar Kapısi'dır (Ek 1-A4). Bu kapının, ani huruç hareketleriyle kaleyi kuşatanları tehdit etmek amacıyla açılmış bir "çıkış kapısı”" (hurûc kapısı) olduğu düşünülebilir. ${ }^{49}$ Bu nedenle Seğirdim Duvar Kapısı, Topkapı Sarayı'nda bulunan 1838'de çizilmiş "Bahr-i Sefîd Sevâhilinde Kâin Antalya Kal'ası'nın Resm-i Musattahı" adını taşıyan bir resimde "Ali Paşa Kapısı" olarak tanımlanmış ve hendeklerin üzerinden geçirilen bir köprü vasıtasıyla şehrin "varoşa" çıkan iki kapısından biri olarak resmedilmiştir. ${ }^{50} \mathrm{Ne}$ var ki 1815 haritasında bu kapı aracılı̆̆ıly "varoşa" nasıl geçildiğine ilişkin, örneğin bu mevkide bir köprünün olup olmadığına ilişkin kesin bir bilgi yoktur. Kadriye Hüseyin'in 192l'de yaptığı Antalya tasvirinde geçen "iner kalkar köprü, hendek, şurasında burasında bir tarih veya Kur'an ayetleri taşıyan kitabeler bulunan, tasavvur edilemeyecek kalın duvarlar, hepsi yerli yerinde” ifadesinin ise Kale Kapısı için olup olmadığı açık değildir. Dolayısıyla, bu mevkide, hendek içinde dolgu bir yolun bulunduğu ve bu dolgu yol vasıtasıyla hendek üzerinden çarşıya geçildiği düşünülebilir. 1815 haritası ile keşif defterinde de herhangi bir köprüye atıf yapılmamıştır. Kadriye Hüseyin'in söz konusu tasviri için bkz. Kadriye Hüseyin, Mukaddes Ankara'dan Mektuplar, çev. Necmeddin Sahir Sılan, Cumhuriyet Kitap, İstanbul 1999, s. 106.

48 Evliya Çelebi, a.g.e., s. 310.

49 "Çıkış kapısı" kavramı için bkz. Akarca, a.g.e., s. 167.

50

Belleten, Ağustos 2020, Cilt: 84/Sayı: 300; 667-716 
çıkılabildiğine ilişkin hiçbir emare yoktur. Çünkü kapının bulunduğu perde sur üzerinde hendeği aşacak bir köprü gösterilmemiştir.

Perde surlar üzerinde yer alan ve 1815 'te Kaleiçi'nin iki kapalı kapısından ilki olan

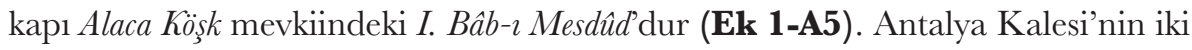
Bâb-ı Mesdûd"undan biri olan - diğeri "Hadrianus Kapısı"dır- bu kapının ilk ne zaman açıldığı bilinmemektedir. Öte yandan 19. yüzyılın ikinci yarısında buradaki dış surun üzerinde bir kapı açılmış ve bu kapıya "Yeni Kapı" adı verilmiştir. Dolayısıyla, 1815 haritasında perde sur üzerinde yer alan I. Bâb-ı Mesdûd, aynı mevkideki dış sur üzerinde "Yeni Kapı"nın açılmasından sonra tekrar işlev kazanan kapı olmalıdır. Gerçekten de 1839'da Alaca Köşk mevkiindeki surlara "sagîr bir kapı" açılması için talepte bulunulmuş, ${ }^{51} 1846$ 'ya tarihlenen bir tahriratta da ahalinin ihtiyacı için - reayanın Kaleiçi'ne "sı̆̆ışamayıp" kale dışına taşınması nedeniyle- kalenin güneydoğusunda şehrin Müslüman ve Hıristiyan sakinlerinin bir arada yaşadığı Makbule Mahallesi sonundaki kale duvarında bir kapı açılması, hariçte ise hendek üzerinde taştan bir köprü bina edilmesi talebi tekrar edilmiştir. ${ }^{52} \mathrm{Bu}$ kapının dışındaki cadde ise 1870'lerde bile "Yeni Kapı Caddesi" olarak adlandırılmıştır. ${ }^{53}$

Burada son olarak, haritada kapalı halde gösterilenler de dâhil, perde surlar üzerindeki tüm kapıların, kaleden çıkan askerlerin daha savunmasız olan sağ taraflarını surlara verecek şekilde konumlandırıldıklarını söylemek gerekir. Bu konumlandırma, sadece Seğirdim Duvar Kapısı'nın değil, perde surlar üzerindeki tüm kapıların "hurûc kapısı" işlevi görmüş olabileceğini düşündürtmektedir.

\section{b. Toprak Şerit Üzerinde Geçişi Sağlayan Kapılar}

1815 haritasında perde surlar ile dış surlar arasında kalan toprak şeridin oluşturduğu bölümün, duvarlarla birbirinden ayrıldığı görülür. Bu bölümler arasındaki geçişler ise biri Kebîr Kapi'nın doğusunda (Ek 1-B1), diğer üçü batısında (Ek 1-B2, B3, B4) yer alan ve haritada içi kahverengiyle boyanmış şekilde çizilen kapılar vasıtasıyla sağlanır. Örneğin, güneydeki dışs sur duvarlarının önündeki geniş toprak şerit ile Değirmen Burcu'nun önündeki toprak şeride ve Zeytinlik adıyla

51 Burada bir kapı açılma talebinin sebebi Rum nüfusun artması ve Kaleiçi’nin bu nüfus artışını karşılayamamasıydı. Bu nedenle Rumlar sur dışına çıkmayı talep etmişlerdi. Bkz. BOA. İ. HR. 2-51, lef. 2.

52 BOA. A.\} MKT. 46-12; BOA. A.\}MKT. 125-81.

53 AŞS. 91/ sayfa 2. 
tesmiye olunmuş, içinde topların bulunduğu ve nihayetinde perde surun bittiği alana sadece bu kapılar aracılığıyla geçilebilmektedir.

Bu vaziyetten anlaşıldığı üzere bu kapılar, hendeği ve perde surları aşabilen saldırganlara karşı kalenin savunmasında önemli bir işleve sahiptir. Bu işlevin en güçlü şekilde tanımlandığı yer ise Kebî Kapı'nın karşısındaki toprak şerittir. Burada eşit ve mütenazır olmayan kuleler ve muhtelif kapılar arasında kalan toprak şerit vasıtasıyla şehrin giriş kapısı, dar ve muhacimler için tehlikeli bir avlunun ardına alınmıştır. ${ }^{54} \mathrm{Bu}$ dar alan, müdafilere, kalenin içine girmek için Keb̂r Kapı'yı zorlayan saldırganları yok etme imkânı vermektedir. ${ }^{55}$

\section{c. Diş Surların Üzerindeki Kapılar}

1815 haritasında dış surlar üzerinde on farklı noktada (biri kapalı) on iki kapı resmedilmiştir. Mermerli Köşk mevkiinden itibaren bu kapıların isimleri şöyledir: Mermerli Köşk'te falezlere açılan Küçük Kapı (Ek 1-C1); ${ }^{56}$ Alaca Köşk Burcu'nun doğusunda yer alan ve günümüzde "Üç Kapılar" ve "Hadrianus Kapısı" olarak da bilinen

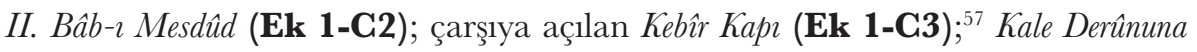
Giden Kapı (Ek 1-C4); İskele Tarafina Giden Kapı (Ek 1-C5); "Tophane Kapıs" olarak da adlandırılan Kemikli Kapı (Ek 1-C6) ${ }^{58}$ I. Bahçe Kapısı (Ek 1-C7); Tabya Kapısı (Ek 1-C8); diğer adı "Hasbahçe Kapısı" olan II. Bahçe Kapısı (Ek 1-C9); 59

54 Aşkıdil Akarca bu tür kapıları "avlulu kapı" adıyla tanımlamıştır ve avlulu kapılardan bazılarında çeşme ya da sarnıç bulunduğunu yazmıştır. Bkz. Akarca, a.g.e., s. 155, 166. Antalya Kalesi’nin Kebîr Kapısı önünde, dış sur ile perde sur arasında kalan bu “avlu” bölümüne, 1819'da taş kemerli ve taş tekneli bir çeşme inşa edilmiş, çeşmenin üzerine katran ağacından, üstü tahta kaplı kiremit çatı eklenmişti. Bkz. BOA. D. BŞM. BNE. d. 16224, lef. 2.

55 Eyice, a.g.m. s. 235. 1472'de Papalık ordusunun Antalya'ya yönelik saldırısının savuşturulduğu yer, muhtemelen, Kebîr Kapı ile Kemikli Kapı arasında kalan bu alandı. Bkz. Hellenkemper; Hild, a.g.e., s. 335.

56 Rifat Özdemir muhtemelen AŞS. 3/124'teki “kal'a-ı mezkûrun Âsitâne Kapusu yesârî tarafindan Hıdırlı nam mahalle varnnca" ifadesinden hareketle, bu kapının Âsitâne Kapısı olduğunu iddia etmiştir. Bkz. Özdemir, a.g.m. s. 136. Ne var ki keşif defterinde bu kapı Küçük Kapı (Mermerli Köşk tahtında derya tarafinda olan Kü̧̈ük Kapu) olarak adlandırılmıştır. Bkz. BOA. C. AS. 840-35837, lef. 3/35.

57 Bu kapı keşif defterinde Kebîr Kapı olarak tanımlanmıştır. 3 numaralı şer'iyye sicilinde "Âsitâne Kapısı” olarak adlandırılan kapı da bize göre bu kapıdır. Zira AŞS. 3/124'te Antalya Kalesi sağ ve sol olmak üzere iki bölüme ayrılmış, Keb̂̂r Kapı'nın (yani Âsitâne Kapısı'nın) sol tarafinda Karakaş Câmi ile Hıdırlık Burcu'na; sağ tarafinda ise Baruthane Burcu'na atıf yapılmıştır. Bkz. AŞS $3 / 124$.

58 Süleyman Fikri, Antalya Livası Tarihi, İstanbul 1338, ss. 33-35.

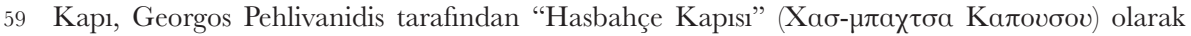
tanımlanmıştır. Bkz. Georgos Pehlivanidis, Attáleia kai Attaleiótes, Pamfylía, Lykía, Pisidía, Kilikía A, 
Gümrük Kapısı (Ek 1-C10); "Tuz Kapısı" adıyla da bilinen Debbağhane Kapısı (Ek 1-C11) ${ }^{60}$ ve Merdivenli Kapı (Ek 1-C12).

Dış surlar üzerindeki bu kapılar içinde 1815'te "varoşa” çıkışı sağlayan tek kapı şehrin ana giriş kapısı olan Kebîr Kapı'dır. Ana giriş kapısı olduğu için Kebî Kapı, adından da anlaşılacağı üzere tekerlekli araçların ve develerin geçebileceği genişliktedir. Kapı ve çevresi Kaleiçi’ne gelen herkesi; tüccarları, seyyahları ya da yolcuları karşılayan ilk yerdir. Bu nedenle seyyahların ilgisini fazlasıyla çekmiş, örneğin 1886'da Antalya'ya gelen Süleyman Şükrü, Kebî Kapı'nın bulunduğu, "kentin garba düşen şarampolü kenarındaki büyük çarşıya bakan dağ misali duvar"dan bahsetmiş ve duvara - bir imar faaliyetinin nişanesi olabileceğini iddia ettiği- Sultan Mahmud'un tuğrasının işlendiğini yazmıştır. ${ }^{61}$

Şehrin savunması açısından bakıldığında, kalenin ana giriş kapısı olan Keb̂̂r Ka$p \imath$ 'nın mutlak surette sıkı tahkim edilmiş olması, burçların himayesi altına alınmas1 gerektiği açıktır. Bu nedenle Keb̂r Kapı, haritada görülebileceği gibi iki burcun arasında yer alan ve keşif defterinde Карı Burcu olarak adlandırılan bir burcun içindeydi. Ayrıca, bu mevkide perde surlar üzerinde de olduğu gibi tek bir kapı yoktur; iç içe geçmiş üç kapı vardır. Mustafa Raşid Efendi bu kapılardan Orta Kaleiçi'ne açılanını Kale Derûnuna Giden Kapı, limana açılanını ise İskele Tarafina Giden Kapı olarak tanımlamıştır. Bu mevkide pek çok kapı olması nedeniyle -perde surlar üzerindeki iki, çarşı tarafındaki bir kapı da düşünüldüğünde buradaki kapı

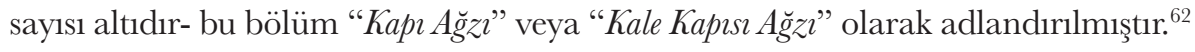
İç içe geçmiş kapıların haricinde Kebî Kapı, biraz evvel de ifade edildiği gibi, ar-

Athína 1989, s. 82.

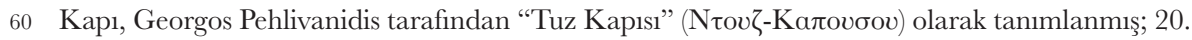
yüzyılın başlarına tarihlenen belgelerde de bu isimle anılmıştır. Bkz. Pehlivanidis, a.g.e., s. 82; BOA. İ. DH. 1454-17, lef. 2-1. "Tuz Kapısı" adının nereden geldiği malum değildir; belki de isim Zanailoğlu Strati’nin iskeledeki tuz mağazası nedeniyle verilmişti. Bununla birlikte Tuz Kapısı debbağhanelerin olduğu bölümde idi. Dolayısıyla "Tuz Kapısı" adının derilerin tuzlanmasıyla da ilişkisi olduğu düşünülebilir. Zanailoğlu Strati’nin iskelede tuz mağazası için bkz. BOA. ML.VRD.TMT.d-9665.

61 Kırçınzade Süleyman Şükrü, Seyahatül-Kübra, yay. Salip Şapçı, Eğirdir Belediyesi Yayınları, Eğirdir 2005, s. 61. Sultan II. Mahmud'un tuğrasını taşıyan kitabe, Tekelioğlu İsyanı'nın bastırılıp kalenin Osmanlı Devleti'nin eline geçmesinden ve bu makalede ele alınan imar faaliyetinden sonra, 1818'de burca işlenmiştir. Günümüzde Kaleiçi’ndeki Etnografya Müzesi’nin bahçesinde sergilenen kitabede şu yazılıdır: "Müşerref eyledi el-hakk kal'a-i tuğrâ-yı sultânı mehâbet-ı âsârı hayrelendirdi çeşm-i düşmânı tavîl-i ömr-i nuh ile mu'ammer eylesun Allah sebeb-i ihyâsı sultan-ı cihân Mahmud hâkânı sene hicri 1233."

BOA. D. BŞM. MHF. d. 13237, lef. 4; BOA. İ. MVL. 296-12002. lef, 16-1. 
dında bulunduğu avluyla, çifte girişler, köşeli veya yılankavi geçitler ve hendek üzerinde yer alan en az bir köprüyle daha tahkim edilmişti. Kebîr Kapı'nın 17. yüzyılda da benzer şekilde tahkim edildiğini Evliya Çelebi’nin yazdıklarından anlamak mümkündür. Evliya Çelebi, "Varoş Kapısı" olarak tanımladı̆̆ı Kebîr Kapı'nın bu özelliklerine değinmiş, Antalya Kalesi'ni dışarıya bağlayan ve "Şahrah” adı da verilen büyük kara kapısının "birbiri içine geçmiş, yedi kat eğri büğrü, kimi doğuya kimi batıya bakan bir geçit” olduğunu yazmıştır. Seyyah, buradaki her bir kapı arasında "nice bin hile ve şeytanlıklar olduğunu", "Varoş Kapısı"ndan başka hiçbir yerden karaya çıkılmadığını, tüm şehir halkının bu kapıya muhtaç olduğunu sözlerine eklemiştir. Seyyahın, "her bir küçük kapının arasında nice bin hile ve şeytanlıklar olduğu" ifadesi ile "asma demir kafesler ve çeşit çeşit savaş aletleri asılı ve cephane ile bezeli kapılardı" sözünü, bu mevkide bulunan ve perde sur üzerindeki geçişi sağlayan kapıların kalenin savunmasına dönük işleviyle bir arada düşünmek gerekir. ${ }^{63}$

1815 haritasında kale dışına açılan dış surlar üzerindeki diğer üç kapı ise Merdivenli Kapı, Tabakhane Kapısı ve Gümrük Kapısı'dır. Limana, dolayısıyla denize çıkışı să̆layan bu üç kapı, Evliya Çelebi'nin seyahatnamesinde; "Büyük Liman Kapısı", "Ortanca Kapı" ve "Küçük Kapı" olarak adlandırılmıştır. ${ }^{64}$

Evliya Çelebi’nin "Büyük Liman Kapısı" adını verdiği kırk taş merdivenle limana inen güneye nazır kapı, 1815 haritasındaki Merdivenli Kapı'dır. Öte yandan 19. yüzyıla tarihlenen bazı kaynaklarda bu kapının adı "Su Kapısı" olarak geçmektedir. ${ }^{65}$

Evliya Çelebi’nin kemeri üzerindeki beyaz mermerde tam bir insan boyunda derviş tasviri olduğunu ifade ettiği ve gümrük binasına çok yakın olduğunu söylediği "Orta Kapı" ise Debbağhane Kapısı olmalıdır. ${ }^{66}$

Evliya Çelebi, a.g.e., s. 310. Kalelerin ana kapıları üzerinde bu şekilde silah teşhir edilmesi veya silah kabartmaları bulunması, kapının ve kalenin korunması çabasıyla ilişkiliydi. Bu şekilde, kapının ve kalenin silahların himayesinde olduğu açıklanmak istenmiş gibidir. Bkz. Akarca, a.g.e., s. 165.

Evliya Çelebi, a.g.e., s. 311.

Charles Wilson, Handbook for Travellers in Asia Minor, Transcaucasia, Persia, etc., London 1895, s. 122.

Süleyman Fikri Erten bana göre hatalı bir şekilde üzerinde derviş tasviri bulunan "Orta Kapı"nın, "Husûsî Muhasebe tarafindan yaptırılmış olan cesîm un fabrikası önünde cenûba nâzır nakışlı kapı" olduğunu iddia etmiştir. Ne var ki Evliya Çelebi’nin bahsettiği "Orta Kapi”, Debbağhane Kapısı'dır; Süleyman Fikri ise esasında Hasbahçe'nin limana açılan kapısı olduğu için "Hasbahçe Kapısı" da denen II. Bahçe Kapısı'nı tarif etmektedir. Keşif defterinde bu kapıya Debbağhane Kapısı denmesinin sebebi ise burada bulunan debbağhanelerdir. Bkz. Evliya Çelebi, a.g.e., s. 310; Süleyman Fikri Erten, Antalya Tarihi, Antalya 1948, s. 70; debbağhaneler için bkz. AŞS. 91/s. 
Evliya Çelebi’nin adını verdiği diğer kapı "Gümrük Kapısı"dır ki, kapı 1815 haritasında da bu isimle anılmıs, 1835'e ait bir kayıtta ise "Balçık Kapı" olarak zikredilmiştir ${ }^{67}$ Seyyaha göre bu gayet küçük bir kapıydı ve kıbleye bakıyordu. Gümrükhane bu kapının iç tarafinda yer alıyordu. Bu bölge aynı zamanda hanların olduğu ticari bölgeydi. Burada; "Bezir Hanı", "Kapan Hanı", "Dur Veli Hanı", "Pirinç Hanı", "Murad Paşa Hanı", "Çavuş Hanı", "Urum Ali Hanı", "Serçe-i Nebi Hanı" isminde büyük odalı hanlar vardı. Mısır ile ticaret bu kapı üzerinden yapilıyordu ${ }^{68}$ Gümrükhane ve çevresi 19 . yüzyılda da limanın ticari aktiviteye tahsis edilmiş bölümüydü. ${ }^{69}$ Denize bakan kale duvarının adı "Gümrük Hisarı" idi. ${ }^{70}$ Gümrükhane dışında birçok han -"Elmalı Hanı", "Kadı Paşa Hanı", "Yeni Han", "Uzun Han" gibi- ve müstakil oda ile ambar bu muhitte yer alıyordu. ${ }^{71}$

1815 haritasında dış surlar üzerindeki Bâb-ı Mesdûd olarak tanımlanmış kapalı kapı 20. yüzyıl başlarında "Çiçekli Kapı" olarak adlandırılan, günümüzde "Üçkapılar" olarak bilinen "Hadrianus Kapısı"dır. ${ }^{72}$ Imparator Hadrianus'un M.S. 2. yüzyılda Antalya'yı ziyareti şerefine inşa ettirilen kapının bulunduğu kapalı alan ilk olarak 1870’lerde kazılmak istenmiş, ancak buna muvaffak olunamamışt. ${ }^{73} \mathrm{Kap1}$, 18811882'de Mutasarrıf Turhan Paşa'nın girişimleriyle başlatılan hafriyat çalışmaları sonucunda, bu mevkideki duvarların yıktırılı tarihi kapının gün yüzüne çıkarılmasıyla tekrar açlmıştır. ${ }^{74}$ Hicri 1317 Konya Vilayeti Salnamesi'nde bu çalışmalar

$182-1$.

67 AŞS 6/73.

68 Evliya Çelebi, a.g.e., s. 314.

69 Gümrükhane binasının 1869'da harap halde olduğu ve bazı yerlerinin tamir edilmesi gerektiği bildirilmişti. Ocak 1906'da çıkan şiddetli firtına nedeniyle buradaki burçlar yıkılmış, birkaç kişi ölmüş ve iskele yolu tıkanmıştı. Bkz. BOA. İ. DH. 591-41111; BOA. DH. MKT. 1055-9.

70 AŞS 6/75.

71 Örneğin Tekelioğlu Hacı Mehmed Ağa’ya ait Yeni Han’ın yirmi üç odası vardı; hanın bitişş̆ginde, gümrük görevlilerinin ikamet ettiği odalar bulunuyordu. Uzun Han'da ise ticari mağazalar vardı. Bkz. BOA. D. BŞM. MHF. d. 13237, lef. 3, 6.

72 Süleyman Fikri, Antalya Livası Tarihi, s. 35.

73 E. J. Davis, yetkililerin 1872'de buradaki girişi tekrar açmak için girişimde bulunduklarını, ancak duvarın iç kısmında, girişin hemen ardında bir ev olduğunu ve ev sahibinin bu işe onay vermediğini yazmıştır. Bkz. E. J. Davis, Anadolu, 19. Yüzynlda Karya, Frigya, Likya ve Psidya Antik Kentlerine Yapılan Bir Gezinin Öykiusï, çev. Funda Yılmaz, Arkeoloji Sanat Yayınları, İstanbul 2006, s. 163.

74 Burhan Cağlar, İngiliz Said Paşa ve Günlï̈̆̈̈ (Jurnal), Arı Sanat Yayınevi, İstanbul 2010, s. 243. Kapı hakkında Lanckoronski şunları yazmıştır: "Antalya'daki eski yapılar arasında en kayda değer olanı, şehrin doğusundaki üç kemerli kapıdır. Biri Iulia Sancta Kulesi diye adlandırılan iki 
esnasında kapının üzerinde "nakş ve kalemi fevkalâde bir maharetle yapılmış ve ehl-i rağbetin nazar-ı hayretini celb etmiș” bir zafer takına tesadüf edildiği, takın üzerindeki bakırdan imal edilmiş yazıda "Roma imparatorlarından Hadrianus'un şerefine mahsustur" ibaresinin görüldüğü ve bu hurûfun o vakit Müze-i Hümayun'a gönderildiği bilgisi vardır. ${ }^{75}$

Dış surlar üzerindeki bir diğer önemli kapı da Kebîr Kapı'nın batısında yer alan ve haritada Kemikli Kapısı olarak adlandırılan kapıdır. Haritada Ali Paşa Sarayı olarak işaretlenen bölüme doğrudan girişi sağlayan Kemikli Kapl, bazı kaynaklarda "Tiberius Kapısı” olarak tanımlanmıştır. Örneğin Süleyman Fikri bu kapının şehirde İmparator Hadrianus adına inşa edilen iki kapıdan biri olduğunu iddia etmiş; ancak 1844'te Mazhar Paşa tarafindan yıktırıldığını ve "el-yevm Tophane Kapısı ismiyle yâd edilen mevkide" bulunduğunu yazmıştır. ${ }^{76} 20$. yüzyılın başlarına tarihlenen pek çok başka kaynakta da kapı "Tophane Kapısı" adıyla tesmiye edilmiştir."

\section{d. Baruthane Burcu'ndan Limana İnen Duvar (Ek 3-D) ile Mevlevihane ve Türbeler Bölümü'nü Çevreleyen Duvar (Ek 3-F) Üzerindeki Kapılar}

Baruthane Burcu'ndan limana inen duvar hattı üzerinde iki farklı noktada iki kapı vardır. Mustafa Raşid Efendi bu kapıları Cenûb Tarafina Mürûr Eden Kapı (Ek 1-D1)

kule arasına sıkıştırılmış olan kapı, surlarla çevrili şehrin bir zamanlar ana girişlerinden biriydi. Şimdi ise molozlar arasında birkaç ayak yükselmektedir ve sadece dış taraftan görülebilmektedir. Kapı iç taraftan yapılarla kapanmıştır. Anıt oldukça iyi korunmuş olmasını, uzunca bir süre dış yüzünün bir duvarla örtülü olmasına borçludur. Birkaç yıl önce bu duvara bir delik açılmıştır." Bkz. von Karl Grafen Lanckoronski, Pamphylia ve Pisidia Kentleri, c. I, çev. S. B. Gün, Suna-İnan Kıraç Akdeniz Araştırmaları Enstitüsü Yayınları, İstanbul 2004, s. 10.

KVS. Def’a 28, Konya 1317, s. 196.

76 Süleyman Fikri "Tiberius Kapısı" (bazı kaynaklarda "Batı Kapısı”) olarak adlandırdığı kapı hakkında şunları yazmışır: “... garb cihetine nâzır olup, Olbia, Phaselis, Termessos, Sagalassus, Kretapolis ve sâir kasabalara giden yolun mebde' i’tibâr olunurdu. Bu kapı üzerinde büyük bir heykel dahi mevcut idi ki kadîm Yunanlıların Zeus'a ve-yâhûd deniz ilâhı Poseidon'a mahsûs idi. İş bu kapı (1844-1260) tarihinde Mazhar Paşa tarafindan yıktırılmış ve elyevm ne kapı ne de heykelden bir nâm ve nişân kalmıştır.” Bkz. Süleyman Fikri, Antalya Livası Tarihi, ss. 33-35.

775 Şubat 1906 tarihli bir belgede "Tophane Kapısı", "münhedim ve mâil-i inhidâm” olduğu; Mart 1907 'de ise ittisalindeki burcun çökmekte olduğu gerekçesiyle zikredilmiştir. Kapı, Süleyman Fikri'nin 1922'de çizdiği şehir haritasında da bu adla anılmıştır. Georgos Pehlivanidis ise kapının

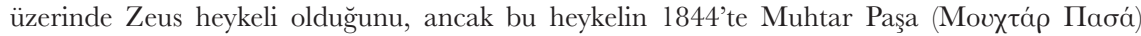
tarafindan yıktırıldığını, Mutasarrıf Turhan Paşa zamanında burada kazı yapıldığında kapının ön cephesinde bir yazıt bulunduğunu iddia etmiştir. Bkz. BOA. BEO. 2756-206645, lef. 1; BOA. I.DH. 1454-1325. Ra/17; Süleyman Fikri, Antalya Livası Tarihi, s. 198; Pehlivanidis, a.g.e., s. 98. 
ve İskeleye Giden Kapr (Ek 1-D2) şeklinde adlandırmıştır. 1834'te Antalya Limanı'na çıan Alexander William Kinglake'in iç kaledeki (Ali Paşa Sarayı'nın olduğu bölge) ikametgâhında oturan Muhassıl Osman Paşa ile görüşmek için geçtiğini belirttiği kapılardan ilki İskeleye Giden Kapı, diğeri ise "iç kalenin kapısı" adını verdiği Cenûb Tarafina Mürûr Eden Kapi' olmalıdır. ${ }^{78}$

Mevlevihane ve Türbeler Bölümü'nü çevreleyen duvar üzerinde tek bir geçit (veya kapı) yer almaktadır. Bu yapı bölümün güney batı köşesinde, haritada belli belirsiz göze çarpan bir merdivenin üzerinde bulunmaktadır. Ne haritada ne de keşif defterinde adlandırılan bu yapı, esasında bir geçit görünümündedir ve bu nedenle haritada gösterilen diğer kapılar gibi numaralandırılmamıştır.

\section{e. İç Surların Üzerindeki Kapılar}

1815 haritasında I. iç sur üzerinde iki farklı noktada üç kapı; II. iç sur üzerindeki üç farklı noktada ise dört kapı vardır. I. iç sur hattı üzerindeki ilk kapı, Merdivenli Kapı'nın kuzeyinde yer alan ve haritada ismi belirtilmeyen bir kapıdır (Ek 1-D3). Diğer iki kapı ise Paşa Câmi’nin karşısındaki burçtadır (Ek 1-D4, D5).

II. iç sur hattı üzerinde batıdan kuzey doğuya doğru sıralanan kapıların isimleri ise haritada Palamut Kapısı (Ek 1-D6) ve Balk Pazarı Kapısı (Ek 1-D8) olarak belirtilmiş̧tir. Haritada Palamut Kapısı ile aynı burçta yer aldığı görülen Güney Kaleiçi tarafindaki kapı (Ek 1-D7) ile sur hattının sonunda gösterilen Sebilhane Burcu'na yakın üçüncü kapının adı verilmemiştir (Ek 1-D9). Rıfat Özdemir Sebilhane Bur$c u$ yakınında bulunan "Çarşı Kapısı"ndan bahsetmektedir. ${ }^{79}$ Bu kapının, Mustafa Raşid Efendi'nin haritasında II. iç sur hattı üzerinde gösterilen isimsiz son kapı olduğu düşünülebilir. Ancak bana kahırsa çok daha kuvvetli ihtimal, Çarşı Kapısi'nın, Kebîr Kapi'dan geçtikten sonra perde sur üzerinde yer alan çarşıya açılan kapı olduğudur.

Özellikle perde surlar ve dış sur duvarları üzerinde bulunan bu kapıların birçoğu, kuşatma yıllarında yıkılmış veya tahrip olmuştu. Bu nedenle, inşa ve tamirleri dolayısıyla keşif defterinde bu kapılardan sık sık bahsedilmiştir. Bunların nasıl inşa ve tamir edileceklerine dair deftere yazılanlar, bu kapıların özellikleri hakkında bilgi vermektedir. Örneğin defterde Kebîr Kapı'nın "kebîr köbri ağacından dört sura kusakl,

78 Alexander William Kinglake, Eothen, Traces of Travel Brought Home from the East, Leipzig 1846, s. 304.

79 Rıfat Özdemir, a.g.m., s. 136. 
kablu bayrak demirli ve asma kilitli sair âlât-ı âheni ile mükemmel çifte kanadlı", ${ }^{80}$ Kemikli Kapi'nın "keb̂̂r köbri ağacrndan dört sira kuşakl ve dirhem başhkl, Semarkand asma kilidli, bayrak demirli ve sair âlât-ı âheni ile mükemmel çifte kanadlı", ${ }^{81}$ Merdivenli Kapi'nın "kebîr köbri ăgactndan, dört sira kuşaklı ve kablu bayrak demirli ve sair âlât-ı âheni ile mükemmel iki kanadlı", ${ }^{82}$ Cenûb Tarafina Mürûr Eden Kapi'nın "çift kanadl, dört sira kuşakl ve mismarlı", ${ }^{33}$ Seğirdim Duvar Kapısı'nın "kebîr köbri ağacından, dört sıra kuşakh, kilitli ve çifte kanadl"" olarak tekrar inşa edileceği notu düşülmüştür. ${ }^{85}$

\section{1815 Haritası'nda Antalya Kalesi'nin Burçları}

Mustafa Raşid Efendi’nin çizdiği haritada dikkat çeken bir diğer yapı grubu, sur duvarlarının üzerine oturan ve en önemli işlevi, sağladıkları yükseklik avantajıyla savunmacıların atış menzilini genişletmek ve surları yandan gelebilecek saldırılara karşı korumak olan burç ya da kule adıyla bilinen yapılardır. ${ }^{86}$

Haritada I. iç sur üzerinde dokuz, II. iç sur üzerinde on sekiz burç resmedilmiştir. Ancak haritada dendânsız olduğu görülen bu burçların hiçbiri adlandırılmamış, keşif defterinde de bunlara ilişkin herhangi bir bilgi verilmemiştir. Bunun nedeni, kuşatma döneminde kalenin iç bölümlerinin çok fazla tahribata uğramaması olabilir. $^{87}$

Haritada perde surlar üzerinde ise üç burç gösterilmiş, ancak bunlar hakkında bilgi verilmemiştir. Haritadan anlaşıldığı kadarıyla bu burçlar, perde surlar üzerinde yer alan kapıların güvenliğini sağlamak amacıyla yapılmıştır. Örneğin, Baruthane Burcu'nun karşısında yer alan Seğirdim Duvan Kapısı, buradaki burcun içindedir (Ek 2-A3). Keşif defterinde ise Kebîr Kapı'nın karşısındaki perde sur üzerindeki Kapı Burcu zikredilmiştir (Ek 2-A1). ${ }^{88}$

BOA. C. AS. 840-35837, lef. 5/109, 110.

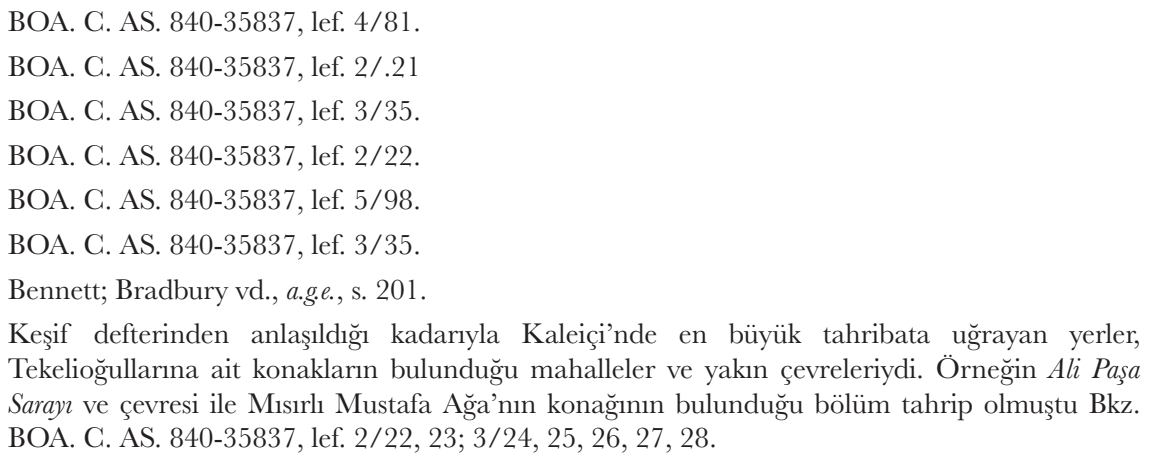
Tekelioğullarına ait konakların bulunduğu mahalleler ve yakın çevreleriydi. Örneğin Ali Paşa Sarayı ve çevresi ile Mısırlı Mustafa Ağa'nın konağının bulunduğu bölüm tahrip olmuştu Bkz. BOA. C. AS. 840-35837, lef. 2/22, 23; 3/24, 25, 26, 27, 28. 
Harita ile keşif defterinde tanımlanan burçların çoğu, dış surlar üzerindedir. Dış surlar üzerinde ikisi limanda deniz içinde olmak üzere, toplam elli dokuz burç vardır. Bunlar, farklı dönemlerde yapıldıkları için düzensiz bir şekilde ve ortalama 30 ila 40 metre aralıklarda bulunurlar. Genellikle iki katlı tesis edilmişlerdir ve çatılarında bir platform vardır. ${ }^{89}$ Keşif defterinde belirtildiği gibi üst kata geçişler dış merdivenlerle (burc nerd-bânn) ${ }^{90}$ platforma geçişler ise iç merdivenlerle sağlanır. ${ }^{91}$ Merdivenli Kapi'dan itibaren haritada ve keşif defterinde diş surlar üzerinde gösterilen burçlardan isimleri zikredilmiş olanlar şunlardır: Çatılı Mühimmât Burcu (Ek 2-B1), "Burc-1 Kebîr" ya da bilinen adıyla Hidırlk Burcu (Ek 2-B2), Alaca Köşk Burcu (Ek 2-B3), Uzun Burc (Ek 2-B4), Köşe Burcu (Ek 2-B5), Zindan Burcu (Ek 2-B7), Sebilhane Burcu (Ek 2-B8), Kapr Burcu (Ek 2-B9), ${ }^{92}$ Nevbethane Burcu (Ek

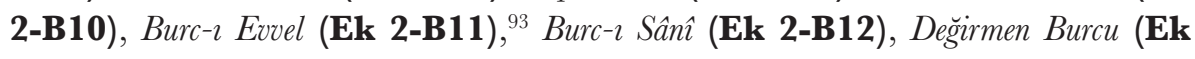
2-B13), Burc- Evvel (Ek 2-B14), ${ }^{94}$ II. Burc (Ek 2-B15), III. Burc (Ek 2-B16), Burcı Râbi (Ek 2-B17), ${ }^{95}$ Çatıl Baruthane Burcu (Ek 2-B18), II. Muhammes Burc (Ek 2-B20), I. Muhammes Burc (Ek 2-B21).

1815 haritası ile keşif defterinde isimi zikredilmeyen, fakat başka kaynaklarda ismi zikredilen dış surlar üzerindeki burçlar ise Evliya Çelebi'nin adını verdiği "Lala Kulesi", "Mehterhane Burcu" ve "Narin Kule" ${ }^{96}$ Lanckoronski'nin "Hadrianus Kapısı"nın güneyinde olduğunu yazdığı "Iulia Sancta Kulesi" (Ek 2-B6) ile Baruthane Burcu'nun batısındaki "Tophane Burcu" (Ek 2-B19) ${ }^{97}$ ve muhtelif kaynak-

89 Hellenkemper; Hild, a.g.e., ss. 324-325.

90 BOA. C. AS. 840-35837, lef. 3/55.

91 BOA. C. AS. 840-35837, lef. 3/50.

92 Kebîr Kapi'nın bulunduğu yerdeki bu burç keşif defterinde "Nevbethaneye muttasıl Kapu Burcu” olarak zikredilmiştir. Bkz. BOA. C.AS. 840-35837, lef. 4/79.

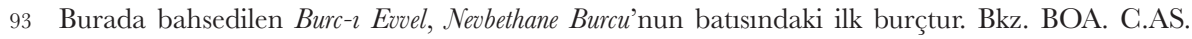
840-35837, lef. $2 / 2$.

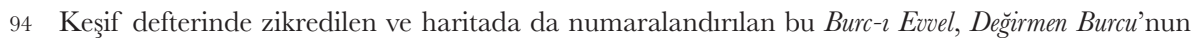
batısındaki ilk burçtur. Bkz. BOA. C.AS. 840-35837, lef. 2/5.

95 Bu burç keşif defterinde bir kere Burc-ı Râbi-i Horasani olarak tesmiye edilmiştir. Bkz. BOA. C.AS. 840-35837, lef. 5/96.

96 Evliya Çelebi, a.g.e., s. 310.

97 Lanckoronski, a.g.e., s. 10. 
larda zikredilen "Bademli Burç", ${ }^{98}$ deniz tarafindaki "Çatal Kule", ${ }^{99}$ "Gazhane Burcu"dur. ${ }^{100}$ Ayrıca, 1834'e tarihlenen bir kayıtta Baruthane Burcu, "Ali Paşa Burcu" olarak isimlendirilmiştir. ${ }^{101}$

Dış surlar üzerindeki tüm bu burçlar hakkında keşif defteri ile farklı tarihlerde şehre gelen seyyahların yazdıkları ya da Osmanlı belgeleri ve şer'iyye sicilleri aracllŏgılla bilgi edinilebilmektedir.

Hakkında bilgi sahibi olduğumuz burçları Mermerli mevkiinden itibaren ele aldığımızda haritada göze çarpan ilk burç çatılı Mühimmât Burcu'dur. Adından da anlaşlacağı üzere bu burcun mühimmât deposu işlevi gördüğü açıktır. Bu durum hem harita üzerinde yazıyla belirtilmiş hem de keşif defterinde "mühimmat vaz olunan burç" ya da doğrudan "mühimmat burcu" şeklinde açılanmıştır. ${ }^{102}$ Burcun bulunduğu mevkii 19. yüzyllın ikinci yarısında da askeri depo olarak kullanılmaya devam etmiştir. ${ }^{103} \mathrm{Ne}$ var ki burcun daha sonra da mühimmat deposu işlevi görmeye devam ettiğine ilişkin bir bilgi yoktur. ${ }^{104}$

Çatılı Mühimmât Burcu'ndan sonra hakkında detaylı bilgi sahibi olduğumuz diğer burç, esasında bir mezar yapısı olarak inşa edilen ve Geç Roma döneminde şehrin savunma yapılarından biri haline getirilen Hidrllk Burcu'dur. ${ }^{105}$ Evliya Çelebi "Kız Kulesi" adıyla zikrettiği Hıdırlk Burcu'nun "katmer gül gibi birbiri içinde, safi beyaz mermerden bir sanatlı görülmeye değer kule" olduğunu yazmıştır. ${ }^{106}$ Keşif defterinde Hıdrrlk Burcu, dört köşeli (murabba) ve yuvarlak (müdevver) olmak üzere iki bölüme ayrılmıştır. Defterde burcun dörtgen zemini ile dairesel bölümü arasındaki geçişin bir merdivenle sağlandığı yazılıdır. Merdivenin sonu ile dairesel bölümün kapısı arasında dik ve tehlikeli bir bölüm vardır. Burada tehlikenin giderilmesi için

98 Bademli (Payamlı) Burç, AŞS. 3/l'da "bahre nâzır Bademli Burç" olarak zikredilmiştir. Bu burç muhtemelen Tabya Bölümü'nde idi. Zira AŞS. 3/1'de "Bademli Tabya"dan, AŞS. 5/108'de ise "Bademli Kale"den bahsedilmiştir.

99 AŞS 6/66.

100 BOA. BEO. 2756-206645.

101 AŞS 5/131.

102 BOA. C. AS. 840-35837, lef. 3/36,37.

103 BOA. HAT. 1224-47828.

104 Topkapı Sarayı'ndaki "Resm-i Musattah"ta tam da bu mevkide bulunan çatılı yapı "zindan" olarak tanımlanmıştır. Bkz. TSMA. E. 9420-1.

105 Hellenkemper; Hild, a.g.e., s. 322.

106 Evliya Çelebi, a.g.e., s. 310. 
demir korkuluk ve parmaklık kullanılmıştır. ${ }^{107}$

Keşif defterine göre Hıdırlk Burcu'nun üzerinde Antalya Kalesi'ndeki ikinci nevbethane yer almaktadır. Ancak defterde de belirtildiği gibi bu nevbethane tamamen tahrip olmuştur. Bu nedenle tekrar bir nevbethane odası inşa edilmesine ihtiyaç duyulmuş ve bu odanın etrafinda katran tahtası kullanılacağı, iki kapılı ve altı pencereli, kiremit çatıl, korkuluklu ve parmaklıklı olacağı vurgulanmıştır. ${ }^{108}$

1825'e tarihlenen bir kayıtta ise Hrdvrlk Burcu'ndaki nevbethane zemininin katran tahtayla döşenmesi talep edilmiş, burcun alt kısmının (murabba' mahalli) mühimmât deposu olarak kullanıldığı belirtilmiştir. ${ }^{109}$ Süleyman Fikri’nin, Osmanlı topçu müfettişlerinden biri tarafindan 1846'da kalede gerçekleştirilen kazıda, Hıdırlk Burcu'nda "akvâm-1 kadîmeye mahsus ok ve şövalyelere ait envai esliha ve levâzımât-1 harbiyeye dair bir depo" keşfedildiğini yazdığı dikkate alınırsa, 19. yüzyılda burcun hem cephane hem de gözetleme kulesi işlevi gördüğü söylenebilir. ${ }^{110}$

Hıdrrlk Burcu'ndan sonra bilgi sahibi olduğumuz diğer burç Hadrianus Kapısı'nın güneyindeki Iulia Sancta Kulesi'dir. Kitabesinde, burcun Iulia Sancta tarafindan inşa ettirildiği bilgisi vardır. Charles Wilson, burcun altında bir su kanalı olduğunu -şehre su sevkiyatı yapılan yerlerden biri herhalde bu mevkide idi- ve II. Mahmud'un ordusunun Haziran 1814 ortalarında bu burcun altındaki su kanalından şehre girdiğini yazmıştır. ${ }^{111} 1815$ haritasında da bu burcun üzerinde bulunduğu sur duvarı, kuşatmada tahrip olmuş yerler arasında gösterilmiştir.

Kapının kuzeyindeki burç, haritada Zindan Burcu olarak tanımlanmışır ve adından da anlaşllacağ̣ üzere muhtemelen zindan işlevi görmüştür. ${ }^{12}$ Zindan Burcu'ndan

107 BOA. C. AS. 840-35837, lef. 3/50.

108 BOA. G. AS. 840-35837, lef. 3/54.

109 AŞS 3/1.

110 Süleyman Fikri, Antalya Livası Tarihi, s. 33. Esasında bu iddia ilk defa Antalyalı Dimitri Danieloğlu tarafindan 1852 yılında yazdığı notlarda şu şekilde dile getirilmişti: "Şimdi bu kule silah deposu olarak kullanılıyor. Buradaki idareciler içeride binlerce ok ve yay, çok eski zamanlardan kalma pas tutmuş zırh ve miğferler olduğunu söylüyorlar. Bu şüphesiz doğru olmalı. 1846-47 yılında toplardan sorumlu bir idareci burayı gözden geçirip pek çok zırh ve miğferi dışarıya atmıştı. Ok ve yaylar hariç bu atılan malzemenin bir kısmını biz almıştık. Aldıklarımızın çoğu Haçlılara belki de biraz daha eski bir döneme ait süvari kıyafetleriydi. Bkz. D. E. Danieloğlu, 1850 Yılında Tapılan Bir Pamphylia Seyahati, çev. Ayşe Özil, Suna-İnan Kıraç Akdeniz Medeniyetleri Araştırma Enstitüsü Yayınları, İstanbul 2010, s. 138.

111 Lanckoronski, a.g.e., s. 11.

112 Wilson, a.g.e., s. 123. 
sonra gelen ve haritada Sebilhane Burcu olarak zikredilen burç, Evliya Çelebi'nin bahsettiği "Lala Kulesi”" olabilir. ${ }^{113}$ Surların dışında bulunan burcun karşısındaki caddeye ise 20. yüzyılın başlarında bile "Sebilhane Caddesi" denilmiştir. ${ }^{114}$

Hakkında en çok bilgi sahibi olduğumuz diğer burç, Evliya Çelebi'nin "Varoş Kapısı" üzerinde bulunduğunu yazdığı ve "Mehterhane Kulesi” adını verdiği burçtur. Bu burç - eğer Evliya Çelebi keşif defterinde Kapı Burcu olarak adlandırılan burçtan bahsetmiyorsa- 1815 haritasında Nevbethane Burcu olarak isimlendirilmiş burç olabilir. Bu durum nevbet kelimesinin anlamıyla da örtüşür. Zira nevbet, "askeri mızıka takımının hükümdarın saray veya otağı önünde davul vurarak icra ettiği musiki" anlamına gelmektedir. Mızıka takımının bulunduğu yere ise "tablhane", "nakkarehane" veya "Nevbethane" adı verilir. ${ }^{115}$ Evliya Çelebi'nin bahsettiği "Varoş Kapısı" üzerindeki "Mehterhane Kulesi"nin geçmişte bu işleve sahip olduğu söylenebilir. ${ }^{116}$ 19. yüzyılda ise Keb̂r Kapi'nın bitişiğindeki Nevbethane Burcu'nun bir gözetleme kulesi işlevi görmüş olması muhtemeldir. Keşif defterinde de burcun üstünde bir nevbethane odası olduğu ifade edilmiştir. ${ }^{17}$ Öte yandan, 19. yüzyılın başlarına tarihlenen bir belgede, burada kale kapıcılarına (bevvab) mahsus bir oda bulunduğundan bahsedilmiştir. ${ }^{118}$

Mevkisi nedeniyle ve haritadan anlaşıldığı kadarıyla bu burç "başkule" işlevi görmüş olmalıdır. ${ }^{19}$ 19. yüzyıla tarihlenen fotoğraf ve gravürlerde bu mevkideki seğirdim terasının oldukça geniş olduğu görülür. Bu durum, burç üzerindeki seğirdim terasının, kalenin bütün surları üzerinde dolaşan yol ağının merkezi olduğunu düşündürtmektedir.

113 Evliya Çelebi bu burcu anlatırken, kalenin bu bölümündeki sur hattını tasvir etmiş ve "bu kale iki kat sağlam otuzar arşın, yedi ve sekizer arşın eninde İskender seddi gibi muhkem duvardır" demiştir. Bkz. Evliya Çelebi, a.g.e., s. 310.

114 BOA. BEO. 2788-209026, lef. 2.

115 Abdülkerim Özayadın, "Nevbet”, TDV Íslam Ansiklopedisi, c. 33, Türkiye Diyanet Vakfi Yayınları, İstanbul 2007, s. 38 ve Zeynep Tarım Ertuğ, "Tablhane”, TDV Íslam Ansiklopedisi, c. 39, Türkiye Diyanet Vakfi Yayınları, İstanbul 2010, s. 334.

116 Evliya Çelebi, a.g.e., s. 310.

117 BOA. C. AS. 840-35837, lef. 5/92.

118 BOA. D. BŞM. BNE. d. 16431, lef. 10. Her kalenin beratlı kapıcılarının (bevvab) olması olağandı. Örneğin 1900'lere kadar Alanya Kalesi’nin kapıları, kapıcılar tarafindan güneşin batmasından yarım saat evvel kapanır ve kilitlenirdi. Bkz. Nazmi Sevgen, Anadolu Kaleleri, Ankara 1959, s. 38.

119 "Başkule" (balâhisar) kavramı için bkz. Ali Boran, "Osmanlı Dönemi Kale Mimarisi”, Osmanh Ansiklopedisi, c. 10, Yeni Türkiye Yayınları, Ankara 1999, s. 347. 
Keşif defterindeki bilgilerden anlaşıldığı kadarıla Nevbethane Burcu'nun üstündeki gözetleme odasının kiremit çatısı bulunmaktadır. Oda penceresinin haritada resmedilmiş parmaklıklarının ise Finike ağacından imal edilmesi istenmiştir. ${ }^{120}$

1819'da Nevbethane Burcu'nun etrafina, tehlikeli bölümlerine kuşaklı tırabzan eklenmiş ya da var olanlar onarılmış, odanın ortasındaki ocak tamir edilmiştir. Nevbethane odasına çıkan merdiven ise asma salıncaktır. ${ }^{121}$

Nevbethane Burcu'nun batısında Değirmen Burcu vardır. Burç adını, bu mevkide bulunan ve limana inen eski değirmen yolundan (kadîm âsiyâb yolu) almış olmalıdır. ${ }^{122}$ Değirmen Burcu'ndan sonra, keşif defterinde kiremit çatılı olduğu belirtilen ve yine defterden anlaşıldığı kadarıyla Antalya Kalesi'nin en yüksek burçlarından (kadd-ı burc 25 zirâ /yaklaşı 19 metre) biri olan Baruthane Burcu yer almaktadır. ${ }^{123}$ Burcun Haçlılar döneminde Venedikli veya Cenovalı olduğu sanılan bir şövalye tarafindan ikametgâh olarak kullanıldığı iddia edilmiş̧ir. ${ }^{124}$ Bununla beraber, burcun cephanelik işlevi gördüğü kesindir, 1834'te "Ali Paşa Burcu" olarak isimlendirilen bu burcun üstünde bir cephanelik bulunmaktadır. ${ }^{125}$

Lanckoronski'nin "Kuzey Şehir Kapısı" olarak tanımladığı, 1815 haritasında Kemikli Kapı olarak adlandırılan kapının hemen yanındaki eski burç, muhtemelen Baruthane Burcu'nun batısındaki "Tophane Burcu”dur. Burcun üzerinde Selçuklu dönemine ait bir kitabe vardır. ${ }^{126}$

Evliya Çelebi'nin şehrin en batısında, Paşa Sarayı köşesinin ötesinde -herhalde bu saray 19. yüzyılda Ali Paşa Sarayı olarak adlandırılan yerdeydi- olduğunu yazdığı

120 BOA. C. AS. 840-35837, lef. 5/93.

121 BOA. D. BŞM. BNE. d. 16224, lef. 2.

122 TSMA. E. 9420-1.

123 BOA. C. AS. 840-35837, lef.1/13.

124 Pehlivanidis, a.g.e., s. 98.

125 AŞS 5/131.

$126 \mathrm{Bu}$ burç hakkında Lanckoronski şunları yazmıştır: "Kuzey Şehir Kapısı'nın hemen batısındaki bir diğer eski kule neredeyse yukarıya kadar günümüze mükemmel ulaşmıştır. Görünen yirmi bir taş sırasının üzerinde bir korniş yer alır. Bunun üzerinde, ikinci ve üçüncü taş sırasını kesen, kuzey cephede iki, doğu ve batı cephelerde birer dar açıklık bulunur. Açıklığın üst kenarı dördüncü taş sırasının içine girecek şekilde yuvarlatılmıştır. Kornişten itibaren on üçüncü taş sırasının üzerinde mazgal dişleri vardır. Bunlar, tıpkı mermer bloklardan oyulu mimari unsurlu çerçevesiyle beraber, Selçuklu dönemine ait büyük yazıtlı levhası gibi geç dönem ilavesidir. Bu yazıt levhasının yanında ve üzerinde yer alan blok taşlar, kulenin diğer kısımlarından belirgin biçimde farklıdır.” Bkz. Lanckoronski, a.g.e., s. 10. 
"Narin Kule" ise muhtemelen keşif defterindeki I. Muhammes Burç'tur. ${ }^{127}$

Son olarak, haritada deniz içinde resmedilen ve Pîrî Reis'in "liman ağzının iki tarafinda birer kule (burgos) vardır ve bu kulelerin birinden diğerine zincir gerilmiştir, yabancı gemi giremez" sözleriyle tarif ettiği burçlar, asıl vazifesi limanı saldırılardan korumak olan burçlardır. ${ }^{128}$ Evliya Çelebi limanın ağzındaki bu iki burcun "kirpi gibi topları olduğunu" ve "dört tarafi korkuttuğunu" yazmıştır. ${ }^{129}$ Bu burçlar hakkında keşif defterinden elde edilebilen bilgi ise güneyde olanının dört köşesinin "telâtum- derya darbyyla" yıkıldı̆̆ı, eğer denize düşerse limanın temizlenmesi gerekeceği, bu sebeple tamir edilmesi gerektiğidir. ${ }^{130}$ Öte yandan, 19. yüzyılın ortalarına tarihlenen İmar Meclisi raporunda buradaki iki burcun üstüne kandil konulacağı bilgisi vardır; bu bilgi, burçların bu dönemde deniz feneri işlevi gördüğünü göstermektedir. ${ }^{131}$

Keşif defterindeki tarifler ile haritada resmedilmiş şekillerinden hareketle burçlar -Osmanlı mimarlarının ekseriyetle tercih ettiği üzere- biçimlerine göre de tasnif edilebilir. Örneğin, limanın güneyinde deniz içinde olan burcun tabanı dört köşeli, deniz üstünde kalan kısmı sekizgen (müsemmen)'dir. ${ }^{132}$ Hıdırlk Burcu'nun zemini dörtgen (murabba), üstü ise yuvarlak (müdevver) olarak tanımlanmıştır. ${ }^{133}$ Haritadaki

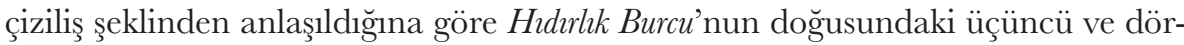
düncü burçlar üçgen (müselles) tiptedir. Kemikli Kapı'nın batısındaki ikinci ve üçüncü burç beşgen (muhammes), dördüncü burç ise üçgen burçtur. Bu burçlar haricinde kalenin burçları dörtgendir.

127 Evliya Çelebi, a.g.e., s. 310. Evliya Çelebi'nin bahsettiği "Narin Kule", kuvvetle muhtemeldir ki Ali Paşa Sarayı'nı çevreleyen dış sur duvarları üzerinde yer almaktadır. Osmanlı kale mimarisinde iç kaleyi tanımlamak için kullanılan "narin kale" veya "narin kule" ifadeleri bu iddianın kanıtı olarak değerlendirilebilir. Narin Kale ve iç kale ilişkisi için bkz. Mahir Aydın, Vidin Kalesi Tuna Boyundaki İnci, İstanbul 2015, s. 36.

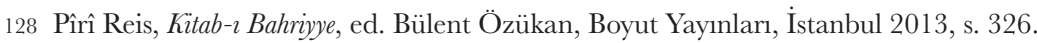

129 Evliya Çelebi, a.g.e., s. 314.

130 BOA. C. AS. 840-35837, lef. 6/119. 12 Haziran 1568'de Rodos Beyi Yahya Bey'e gönderilen hükümden, deniz içindeki bu burçların bu sorunla sürekli karşlaştı̆̆ anlaşılmaktadır. Bu hükümde, Antalya Kalesi’nin "liman ağzında" iki tarafında zincir gerilen kuleleri deniz içinde olduğundan ve derya temevvüç ederek diplerini harap ettiğinden tamire muhtaç olduğu bildirilmiştir. Bkz. Behset Karaca, "XVI. Asırda Antalya Tersanesi ve Burada Gemi Yapımı”, ed. Bedia Koçakoğlu vd. Antalya Kitabı, Palet Yayınları, Konya 2018, s. 83.

131 BOA. A.\} MKT. 236-93.

132 BOA. C. AS. 840-35837, lef. 6/119.

133 BOA. C. AS. 840-35837, lef. 3/48. 
Esasında bu durum, 12. yüzyıldan sonra kale burçlarının biçiminde yaşanan değişime Antalya'da ayak uydurulmadığını gösterir. Çünkü esas olarak Romalıların kullandığı yuvarlak burçlar 12. yüzyıldan itibaren tekrar revaç kazanmış, hem top atışından hem de lağım faaliyetinden korunmak için burçlar yuvarlanmıştı. ${ }^{134}$ Zira nişan veya hedef alınacak belirgin köşeleri olmadığından, yuvarlak burçlara lağım atmak ya da bu burçları top atışıyla tahrip etmek hayli güçtü. ${ }^{135}$

\section{1815 Haritası'nda Kaleiçi’nin Taksimatı}

Mustafa Raşid Efendi'nin haritası, iki iç surun birbirinden ayırdığı üç esas bölüm üzerine çizilmiştir. Duvar tekniği ve malzemesine bakılarak bu iki iç surun Roma ve Bizans devirlerinde mevcut olduğu, bu devirlerde de şehrin 19. yüzyıldaki sur sistemine benzediği iddia edilmiştir. ${ }^{136}$ Haritada iç surlar, tıpkı bunların üzerinde yükselen burçlar gibi dendânsız resmedilmiş, keşif defterinde ise bu duvarlara ilişkin hiçbir tamirat faaliyetinden bahsedilmemiştir; sadece I. iç sur duvarı üzerindeki bir bölüm -yıkık olduğuna işaret edilmek amacıyla- karalanmıştır.

I. iç sur (Ek 3-H) hattı Nevbethane Burcu'ndan başlar, Uzun Çarşı Sokak boyunca devam eder ve iskeledeki Merdivenli Kapı'ya ulaşır. Bu iç surlar üzerindeki kitabelerde şehrin ikinci fethinin hikâyesi anlatılmıştır. Bilindiği gibi Antalya 1215'te Kıbrıs hükümdarı tarafindan tekrar zapt edildiğinde kaledeki Müslümanlar öldürülmüştü. Şehir birkaç sene Kıbrıslıların elinde kaldıktan sonra İzzeddin Keykavus tarafindan sürdürülen ve bir ay devam eden şiddetli bir muhasarayla 1216 başlarında

134 Hıdırlık Burcu'nun kare planlı bir kaide üzerine yükselen yuvarlak kulesi, savaş teknolojisinde yaşanan bu dönüşümden bağımsız olarak değerlendirilmelidir. Zira yapı bir savunma kulesi olarak inşa edilmemiş, benzerlerini görkemli Roma mezarlarında bulan bir anıt mezar olarak inşa edilmişti. Bkz. George E. Bean, Eski Çağ'da Güney Kiynlar, çev. İnci Delemen-Sedef Çokay, Arion Yayınevi, İstanbul 1999, s. 24.

135 Bennett; Bradbury vd., a.g.e., s. 184. Bu değişimin izlerine Antalya Kalesi’nin burçlarında rastlanılmamasının muhtemel nedeni, şehrin lağım atmanın çok güç olduğu hayli taşlık bir zemin üzerinde yükselmesi, ayrıca derin bir hendek ve perde sur ile çevrili olmasıydı. 1812-1814 kuşatmasında Osmanlı ordusuna komuta eden Ali Paşa, Aralık 1812 dolaylarında başkente gönderdiği bir yazıda Antalya Kalesi’ne lağım atmanın güçlügüunden bahsetmiştir. Bkz. BOA. HAT. 1224-47830 E.

136 Yılmaz, Antalya (16. Yüznılın Sonuna Kadar), s. 107. Tuncer Baykara ise I. iç sur hattının şehirdeki Müslümanlar ile gayrimüslimleri ayırmak için 1216'da İzzeddin Keykavus tarafindan, II. iç sur hattının ise on sene sonra Alaaddin Keykubad tarafından yaptırıldığını iddia etmiştir. Bkz. Tuncer Baykara, Anadolu'nun Selçuklular Devrindeki Sosyal ve İktisadi Tarihi Üzerine Araştırmalar, Ege Üniversitesi Basımevi, İzmir 1990, ss. 110-111. 
geri alınmıştı. Antalya Kalesi bu dönemde kapsamlı bir tamir görmüş, I. iç sur hattı birçok kitabeyle donatılmıştı. ${ }^{137}$

Dış surlara yaklaşan bir kalınlık ve burç sıklığı içeren II. iç sur (Ek 3-I) hattı ise Kaleiçi’nin doğu bölümünü Mermerli mevkiinin üstünden başlayıp güneydoğu istikametinde kat eder. ${ }^{138} \mathrm{Bu}$ sur hattı I. Alaaddin Keykubad döneminde kapsamlı bir imar görmüştür. II. iç sur üzerindeki tüm kitabeler, söz konusu inşaat faaliyetinin bu dönemde yapıldığını göstermektedir. Kitabelerde bu hat üzerinde yer alan burçların kimler tarafindan yapıldığı da yazmaktadır. ${ }^{139}$

Haritayı I. ve II. iç surların böldügüü üç esas bölüm üzerinden tasnife tabi tutuğumuzda; Kuzey Kaleiçi, Orta Kaleiçi ve Güney Kaleiçi bölümleri ile karşılaşılır. Bu üç ana bölüm arasında bir tek Kuzey Kaleiçi, her biri müstakil, iç kapılarla geçişin sağlandığı alt bölümlere ayrılır. Bu alt bölümlerden ilki yerleşime açı olan Câmi-i Atîk Mahallesi ve çevresidir. Bu alt bölüm, dış surlar itibariyle Nevbethane Burcu ile başlar, batıdaki Değirmen Burcu ile sona erer (Ek 3-G). Bu iki burç arasında ise

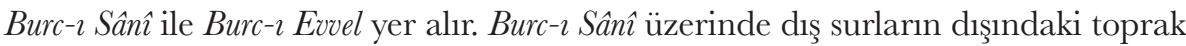
şerit arasında geçişi sağlayan bir kapı bulunur. Nö̀bethane Burcu ile 1920'lerde "Saat Kulesi”" olarak işlev kazanmış burç arasında ise Kebîr Kapı vardır. Kebîr Kapı'nın güneyindeki kapı Kale Derûnuna Giden Kapr olarak isimlendirilmiştir ve Orta Kaleiçi’ne açılmaktadır. Batıdaki kapı ise İskele Tarafina Giden Kapı'dır ve Câmi-i Atîk Mahallesi ve çevresine açılır.

Câmi-i Atîk Mahallesi ve çevresini I. iç sur hattı Orta Kaleiçi'nden ayırır. Bu iç sur, biraz evvel de ifade edildiği gibi Nevbethane Burcu'ndan başlar ve Merdivenli Kap’'ya gelir. Daha sonra ayırıı bir duvar kuzeye, Baruthane Burcu'na uzanarak bölümü kapatır (Ek 3-D). Câmi-i Atîk Mahallesi ve çevresi ile Orta Kaleiçi Bölümü arasındaki geçişler ise ilki Kebîr Kapi'ya, diğeri Merdivenli Kapı'ya komşu iki iç kapı vasıtasıyla sağlanır. Ayrıca, bu bölümün batı tarafindaki İskeleye Giden Kapr aracılığıyla bölüm limana bağlanır.

137 I. iç sur hattı üzerindeki "Fatihnâme" ile ilgili bkz. Scott Redford; Gary Leiser, Taşa Yazılan Zafer Antalya İçkale Surlarnndaki Selçuklu Fetihnamesi, çev. İnci Türkoğlu, Suna-Inan Kıraç Akdeniz Medeniyetleri Araştırma Enstitüsü Yayınları, İstanbul 2008, ss. 18-19.

138 Burhan Varkıvanç'ın da ifade ettiği gibi, dış surlara yaklaşan bir kalınlık ve burç sıklığı içermesi ve her yönden mazgal pencereleri ile donatılmış olması gibi nedenlerle, II. iç surun silahlarından arındırılmış bir nüfusu tecrit etmek amacıyla inşa edildiği iddiası hiç ikna edici değildir. Bu surlar kuvvetle muhtemeldir ki Bizans döneminde Arap akınlarına karşı inşa edilmiştir. Bkz. Varkıvanç, a.g.m., s. 61 .

139 Yılmaz, Antalya (16. Yüzynln Sonuna Kadar), ss. 110-111. 
1815 haritasında bu bölümde gösterilen Eski Câmi, günümüzde "Yivli Câmi” olarak bilinen camidir. Selçuklu dönemine kadar uzanan bir geçmişe sahip bulunan câmi, bir zamanlar Antalya'nın ulu camisi olarak fonksiyon görmüştür. ${ }^{140}$ Eski Câmi’nin merkezinde yer aldığı bölüm, câmiden adını alan Câmi-i Atik Mahallesi'nin yanı sıra Kara Dai ve Ahi Kızı mahalleleri gibi şehrin kadim Müslüman mahallelerine ev sahipliği yapar.

Kuzey Kaleiçi’ndeki bir diğer alt bölüm, Evliya Çelebi’nin "Mevlevihane ile Eski Câmi iç kale gibi altı kuleli bir kat bölme hisardır" sözleriyle tarif ettiği Mevlevihane ve Türbeler Bölümü'dür. ${ }^{141}$ Bölüm dış surlar itibariyle doğusunda Değirmen Burcu ile başlar, batısında Baruthane Burcu ile sona erer (Ek 3-E). Haritada bu bölümün güney tarafindan da bir duvarla kapatıldığı görülür (Ek 3-F). Buradaki duvarlar bu alt bölümü diğerlerinden ayırır. Burası esasen Ali Paşa Sarayı'nın olduğu bölümle irtibatlıdır. Mevlevihane ve Türbeler Bölümü'nün güney tarafinda, günümüzde de mevcudiyetini muhafaza eden iki teras vardır ve ikinci terasın sağ tarafindaki geçit ya da kapı, bölümü Orta Kaleiçi’ne ve limana açar.

1815 haritasında bu bölümdeki iki türbe tanımlanmıştır. Haritanın sağındaki türbenin (Nigar Hatun Türbesi'nin) üzerine "Sultan Korkud'un", solundaki türbenin (Zincir Kıran Türbesi) üzerine ise "Tarikk-i Mevleviyye'den Horasanî Zincir Kiran Baba Hasan Efendi” notu düşülmüştür.

Kuzey Kaleiçi'nde bulunan Ali Paşa Sarayı haritada dış sur hatları takip edildiğinde Baruthane Burcu ile başlayıp I. Muhammes Burç’la biten (Ek 3-B), güneyde limanın üzerinde yükselen ve üzerinde topların olduğu bir duvarla çevrili (Ek 3-A), batı tarafinda I. Muhammes Burç'la başlayıp II. Bahçe Kapısı'nın (Hasbahçe Kapısı) bitişiğindeki burca inen duvarla Hasbahçe'den tefrik olan (Ek 3-A), doğuda ise güneye inen bir başka duvarla Mevlevihane ve Türbeler Bölümü'nden ayrılan (Ek 3-D), esas olarak Ali Paşa Sarayı'na tahsis edilmiş kapalı bir bölümdür. Kemikli Kapı, Ali Paşa Sarayı'nı dış sur ve perde sur arasında kalan toprak şeride çıkışına imkân verir. Perde surlar arasındaki geçişler de kapılar aracılığıyla sağlandığından, hem Hasbahçe'nin perde sur tarafinda yer alan Zeytinlik mevkiine, hem de Mevlevihane ve Türbeler Bölümü'nün perde sur tarafina iki küçük kapı aracılığıyla geçiş sağlanır. Ali Paşa Sarayn ile liman arasındaki bağlantıyı ise bu alt bölümün doğusundaki $C_{e-}$ nup Tarafina Giden Kapı sağlar.

140 Yılmaz, Antalya (16. Yüzynlın Sonuna Kadar), s. 15.

141 Evliya Çelebi, a.g.e., s. 311. 
Kente hâkim konumu, silah deposu işlevi gören Baruthane Burcu ve Hasbahçe ile olan ilişkisi gibi nedenler düşünüldüğünde Ali Paşa Sarayı'nın olduğu bölümün, İbn-i Batuta'nın "kentin beyinin, ailesi ve devlet erkânı ile kapıkullarıyla birlikte kent halkından ayrı olarak yaşadığı bölüm" olarak tarif ettiği, "etrafı surlarla çevrili bir kaleyi andıran yer" olduğu açıktır. ${ }^{142}$ "Bâlâ hisar" adıyla da tesmiye edilen iç kaleler, surlarla çevrili bir şehrin içinde hâkim bir noktaya; hükümdar ya da kumandanın oturması ve düşmanın surları geçmesi ya da şehirde bir isyan çıması halinde içine çekilip müdafaada kalması için ikinci bir kale olarak yapılırd. ${ }^{143} \mathrm{Ali}$ Paşa Sarayı ve çevresinin "iç kale" ya da "bâlâ hisar" olduğu iddiası E. Sperling tarafindan ortaya atılmış, ${ }^{144}$ Hellenkemper ve Hild tarafindan savunulmuştur. ${ }^{145}$ Bölümün, hem içeriden hem dışarıdan toplarla korunduğunu gösteren 1815 haritası ise bu iddiayı görsel olarak da desteklemektedir. ${ }^{146}$

Kuzey Kaleiçi'nin son alt bölümü Hasbahçe'dir. 1815 haritasında Antalya Kalesi’ndeki Hasbahçe'nin iki kapı aracılığıyla diğer bölümlere açıldığı görülmektedir. Hasbahçe, Birinci Bahçe Kapısı vasıtasıyla kalenin batısındaki perde sur ile dış sur arasında kalan Zeytinliğe, İkinci Bahçe Kapısı aracilığıyla da limana açılır.

Kaleiçi'nin diğer iki esas bölümü olan Orta Kaleiçi ile Güney Kaleiçi ise surlar veya ayırıcı duvarlar vasıtasıyla birbirinden ayrılmış alt bölümlerden oluşmazlar, tek başlarına müstakil birer bölüm olarak belirirler. Orta Kaleiçi, I. ve II. iç sur hattı arasında kalır. Nitekim bölüm, Palamut Kapısı, Balık Pazan Kapısı ve haritada adı verilmemiş bir diğer iç kapı ile Güney Kaleiçi’ne; Merdivenli Kapr aracılığıyla da "Merdivenli İskele"ye ve Kuzey Kaleiçi'ne açılmaktadır. Ayrıca, I. iç sur hattının Kebîr Kapı'ya en yakın burcu üzerindeki açı kapı aracılığıyla buradan Kuzey Kaleiçi'ne, Kale Derûnuna Giden Kapr aracılığıyla varoşa geçiş sağlanabilmektedir.

142 İbn-i Battuta, İbn Battuta Seyahatnamesi, cilt: I, çev. Sait Aykut, Yapı ve Kredi Yayınları, İstanbul 2004, s. 335 .

143 Arseven, a.g.e., s. 909.

144 E. Sperling Ali Paşa Sarayı'nın olduğu bölümü kastederek şöyle yazmıştır: "(Kalenin) batı tarafı daha yüksektir, bu kısımdaki kuleler daha sık inşa edilmiş ve bu kesim bir duvarla şehirden ayrılmıştır. Bu iç kaleye (citadelle) Tophane diyorlar.” Bkz. Sperling, a.g.e., s. 67.

145 Hellenkemper; Hild, a.g.e., s. 332.

146 İç kaleden bahseden ilk metin, 1207'deki ilk Selçuklu fethine ilişkin ibn el-Esîr'in anlatımıdır. Bu anlatıma göre Selçuklular tarafindan ikmal yolları kesilen kent büyük bir açmazla karşı karşıya gelmişti. Sıkıntı öylesine büyümüştü ki bir süre sonra kalede bulunan Frenkler ve Rumlar birbirine düşmüştü. Rumlar Müslümanlara haber göndermişler ve kenti onlara teslim edeceklerini bildirmişlerdi. Bunun üzerine Frenkler iç kaleye sığınmak zorunda kalmıştı. Bkz. Redford; Leiser, a.g.e., ss. 13-14. 
Haritada bu bölüm içinde gösterilen Mermerli Köşk mahalli Tekelioğullarına ait köşke ev sahipliği yaptığı için bu adı almıştır. ${ }^{147}$ Gene bu bölümde resmedilmiş ve 19. yüzyılın ortalarında bitişiğinde bir muvakkithane olduğunu bildiğimiz Paşa Câmi ise 1606-1617 arasında yaptırılmıştır. ${ }^{148}$

Güney Kaleiçi, II. iç sur ile şehrin "varoşunu” güneyden kuşatan diş sur hattı arasında kalır. Bölümü çevreleyen dış sur hattı kara tarafinda Hıdırlık Burcu'ndan sonra başlar, kuzeyde Sebilhane Burcu'na varmadan biter. Kara tarafindaki bu dış sur hattı üzerinde otuz bir burç resmedilmiştir. Bölümü deniz tarafindan çevreleyen ve falezlerin üzerinde yer alan dış sur hattı ise Antalya Kalesi'nin savunma işleviyle tanımlanmış alanlarından biridir. Bu nedenle, haritada, II. iç sur hattının falezlerle

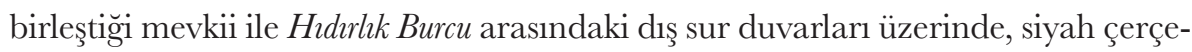
veli içi boş daireler şeklinde çok sayıda top resmedilmiştir. ${ }^{149}$ Haritada, bu bölümde gösterilen son yapı ise Orta Bizans döneminde Pamfilya'nın en büyük kutsal yapısı olan ve bir zamanlar Antalya başpiskoposu tarafindan kullanılan (Panhagia Kilisesi) Yeni Câmi'dir. ${ }^{150}$ Kilise, Sultan II. Bayezid'ın oğlu Korkut tarafından câmiye çevrilmiştir. ${ }^{151}$ Câmi 11 Ağustos 1895 tarihinde çıkan büyük yangından sonra tahrip olmuş, minaresi yandığı için "Kesik Minare" adını almıştır. ${ }^{152}$

Kısacası, haritadan anlaşıldığı kadarıyla, I. ve II. iç surlar ile muhtelif noktalardaki, örneğin Mevlevihane ve Türbeler Böliumü ile Ali Paşa Sarayı ve çevresindeki ayırıcı

147 BOA. D. BŞM. MHF. D. 13237. Süleyman Fikri Erten bu mevkiinin "Romalılardan kalma bir tiyatro olduğunu" iddia etmiştir. Bkz. Süleyman Fikri, Antalya Livası Tarihi, s. 39.

148 BOA. NFS. d. 3230.

149 II. iç sur hattı Güney Kaleiçi’ni diğer bölümlerden ayırmaktadır. Buradan Orta Kaleiçi’ne üç kapı aracılığıyla geçiş sağlanır. Mermerli mevkiine açılan ve 1815 haritasında da adlandırılan Palamut Kapı iç sur hattı üzerindeki ilk kapıdır. Bu mevkii, 1923’te İtalyan Mühendis G. Scarpa tarafından çizilen haritada "Palamut Mahallesi" olarak adlandırılmıştır. İkinci kapı, haritada Yeni Câmi olarak adlandırılmış caminin kuzeyinde yer alan Balık Pazan Kapısı'dır. Üçüncü kapı ise iç sur hattının dış surlara yaklaştığı doğu tarafındadır ve haritada isimlendirilmemiştir. G. Scarpa Haritası ve "Palamut Mahallesi" için bkz. Hasan Moğol, Haritalarla Antalya, Mehter Yayınları, Ankara 1997, s. 38.

150 Redford; Leiser, a.g.e., s. 14.

151 Câminin kiliseye dönüşme sürecine ilişkin mahalli rivayet şu şekildedir: "Sultan Korkut hazretleri Antalya'da bulunduğu sırada bir câmi'-i şerif tesisini arzu edüb hâric-i şehirden atdırdığı bir okun mezkûr câminin aslı olan kiliseye düşmesi ile kiliseyi câmiye tahvîl ettiği rivâyet olunuyor. Harîkden mukaddem câminin sakfinda bir ok muallâk bulunuyordu. Ve mezkûr okun da Sultan Korkut tarafindan atdırılan ok olduğu söylenirdi.” Bkz. KVS. Def'a 30, Konya 1330, s. 526.

152 BOA. Y. A. HUS. 335-66, lef. 2; BOA. DH. MKT. 431-57. 
duvarlar bir arada, dış surların çevrelediği Kaleiçi’ni altı bölüme ayırır. Bu altı ana bölüm dışında yer alan şehrin limanı ise kendi içinde ikiye taksim olmaktadır. Bu bölümlerden ilki, limanın batısındaki gümrük binasını da içine alan "Gümrük Limanı", ${ }^{153}$ diğeri haritada gösterilen kalafatçı dükkânlarının bulunduğu "Merdivenli İskele"dir. ${ }^{154}$ Ayrıca, haritada, kalenin kuzey batısında perde surların sona erdiği yerde, ama dış sur duvarlarının da haricinde, keşif defterindeki ifadesiyle "hâric-i leb-i derya üzerinde" bir bölüm daha göze çarpar. ${ }^{155} \mathrm{Bu}$ bölüm, dış surların çizdiği kavis itibariyle Antalya Kalesi’ne sonradan eklendiği aşikâr olan ve bu surların çevrelediği esas Kaleiçi’nin dışında kalan Tabya'dır.

Savunma amacıyla yapılmış ve toplarla donatılmış Tabya, Antalya Kalesi'nin deniz seviyesine en yakın müstahkem mevkiidir. Bulunduğu yer özellikle seçilmiş bu yapı, muhtemelen, topun yaygın bir kullanım alanı bulmasından sonra eski istihkâmları güçlendirmek için girişilen arayışın sonucu olarak ortaya çıkmıştır. 18. yüzyılda topçuluğun gelişmesiyle birlikte kale mimarisinde önemli değişiklikler yaşanırken, yüksek duvarlı ve kuleli yapıların top ateşine kolayca hedef olması kalelerin daha alçak inşa edilmesine neden olmuş, kalelerden yapılan top atışlarının da alçaktan yapılması prensibi benimsenmişti. Bu dönüşüm tabyalı kale mimarisi düzenini geliştirmişti. Yeni sistemde, özellikle deniz kıyısında bulunan kalelerin kuşatma yapan gemilere karşı top atışı yapabilmesi için, topların su yüzeyine yakın bir hizaya yerleştirilmesine önem verilmişti. ${ }^{156}$ Antalya Kalesi'nde "hâric-i leb-i derya üzerinde" bulunan Tabya da, kuvvetle muhtemeldir ki bu değişimin sonucu olarak ortaya çıkmıştı.

153 Bu bölüme Kaleiçi’nin her tarafindan girilebilirdi. Ancak ticari sevkiyatın da gerçekleştirildiği esas giriş noktası, İskeleye Giden Kapi'dır. Bölüm doğudaki Gümrük Kapısı ve batıdaki Debbağhane Kapısı aracılı̆̆gyla denize açlır.

154 Limanın bu bölümü, tekne inşa edilen ve tamir edilen bölümdür. 19. yüzyllın ilk yarısında burada "şahtur" ve "şalopa" türü küçük tekneler yapıldığı bilinmektedir. 1815 haritasında da burası kalafatçı dükkânlarının olduğu bölüm olarak tanımlanmıştır. Merdivenli Kapi'dan ulaşlabilen bölümün diğer adı "Merdivenli İskele"dir. Bkz. BOA. HAT. 572-28008; BOA. NFS. d. 3230, s. 10.

155 BOA. C. AS. 840-35837, lef. 5/103.

156 John Keegan, Savaş Sanatı Tarihi, çev. Füsun Doruker, Yeni Yüzyıl Yayınları, İstanbul 1995, ss. 478-479; Eyice, a.g.m., ss. 234-236. 


\section{Sonuç}

Osmanlı İmparatorluğu'nun Akdeniz'deki belli başlı kalelerinden biri olmasına rağmen Antalya Kalesi’nin fiziki şemasına ve taksimine ilişkin çok az araştırma yapılmıştır. Şehrin sur planının verildiği Lanckoronski'nin eserinde yer alan 1885 tarihli çizim -ki bu çizim iç surlar üzerindeki burç ve kapıları göstermemekte, kalenin taksimine ilişkin çok az bilgi vermektedir- ve bunu esas aldığı anlaşlan Süleyman Fikri'nin 1922'de çizdiği kale şeması haricinde, Osmanlı döneminden günümüze bir plan ulaşmamıştır. Ayrıca, Kaleiçi’nin Antik dönemden bugüne kadar kesintisiz yerleşim alanı olarak kullanılması, antik şehrin tamamını kapsayan arkeolojik kazı çalışmalarının yapılmasını olanaksız kılmaktadır. Son olarak, sistematik bir şekilde 1914 'te başlayan ve 1930'ların ortalarında biten yıkım süreci maalesef görsel olarak (tam manasiyla) belgelendirilememiştir. Tüm bu nedenler bu önemli tahkimata ilişkin tahlilde bulunmayı güçleştirirken, kalenin 1815'e ait şematik bir planını ve taksimini veren Mustafa Raşid Efendi'nin haritası ile ona eşlik eden keşif defterinin değerini arttırmaktadır. Ayrıca, Osmanlı Arşivinde bulunan kale keşif defterleri arasında, bütüncül bir plan veya haritanın eşlik ettiği çok az belge vardır; dolayısıyla 1815 haritası ile kale keşif defteri bu açıdan da önem arz etmektedir.

Gerçi, Antalya Kalesi'ni tasvir eden bilinen ve günümüze ulaşan bu en eski harita, topografya bilgisinden ve haritacılı̆̆ın teknik araç ve gereçlerinden mahrum bir şekilde çizilmiştir. Haritada surların yön değiştirdiği veya keskinleştiği noktaları izlemek güçtür; mesafeler ölçülmeden, göz kararı küçültülmüştür; yapılar ve mevkiler arasında muvazenesizlikler vardır. Kısacası, bu harita, kalenin mevcut şeması hakkında ancak bir fikir vermektedir.

Ne var ki bu eksikliklerin hiçbiri haritanın değerini azaltmamaktadır. Çünkü Mustafa Raşid Efendi'nin haritası, çizildiği dönem itibariyle kaleyi çevreleyen hendeği, perde surları, perde surlar üzerindeki kapıları, şehrin dış ve iç surlarını, surlar üzerindeki burçları ve kale kapılarını eksiksiz göstermektedir. Dolayısıyla bu çalışmada, harita ve keşif defteri kullanılarak - ve çok defa Kaleiçi'nde de incelemeler yaparak- bu yapıları bulundukları mevkileri göstererek tanımlamak mümkün olmuştur. Örneğin Antalya Kalesi'nin seğirdim terasları ilk defa bu denli ayrıntılı incelenmiş, görsel bir belge olmadığı için daha önce bilinmeyen ya da mevkisi tam olarak tespit edilemeyen birçok kapı ve burca ilk defa bu çalışmada işaret edilmiştir. Keşif defteri ise haritada gösterilen kapı ve burçların şekil, özellik ve işlevleri hakkında bilgi verdiğinden, çalışmada bu hususlara da değinilmiştir. Ayrıca, kale- 
deki çeşitli yapılara ilişkin defterde sunulan nesnel verilerden yararlanılmış, ilgili veriler yapıların niteliğini ve niceliğini saptamakta kullanılmıştır. Tüm bunların dışında, çalışmada Kaleiçi’nin nasıl taksim edildiğine ilişkin açık bir öneri geliştirilmiş; daha önce değinilmemiş Tabya ele alınmış, kalenin toplarla tahkim edilmiş bölümlerinden bahsedilmiş, iç kalenin nerede olduğu, limanın iki farklı bölümden oluştuğu gibi hususlara 1şık tutulmuştur.

Burada son olarak, tüm bu tanımlama ve tespitlerin belirli bir dönem için geçerli olduğunu ifade etmek gerekmektedir. Çünkü çalışmada yer yer gösterildiği gibi; burç, kapı, hatta bölüm isimlerinin yarım yüzyıl gibi kısa bir süre içinde bile değiştiği düşünüldüğünde, tek bir seferde ve tek bir plana ve keşif defterine dayanarak kalenin tüm tarihini anlatmanın mümkün olmadığı açıktır. Ayrıca - her ne kadar Osmanlı döneminde kalenin esas iskân şeması ile taksiminde çok büyük bir değişim yaşanmadığı iddia edilebilse de- Tabya örneğinde olduğu üzere, değişimin, kalenin bölümlenmesine ilişkin de takip edilebilir tarafları vardır. Zira kaleler her şeyden önce askeri yapılardır ve askeri teknolojinin gelişimine bağlı olarak değişmiştir. Ayrıca, içinde insanların yaşadığı yerler olan kaleler, âdem-i merkeziyetçiliğin güçlenmesi gibi toplumsal hayatı etkileyen değişimlerden etkilenmiştir.

\section{KAYNAKLAR}

\section{Arşiv Kaynakları}

\section{Cumhurbaşkanlığı Devlet Arşivleri Başkanlığı Osmanlı Arşivi (BOA.)}

Sadaret Mektûbî Kalemi (A. MKT.)

46-12;125-81; 236-93.

Bâb-ı Âli Evrak Odası (BEO.)

2756-206645; 2788-209026.

Cevdet Askeriye Belgeleri (C. AS.)

840-35837.

Cevdet Dâhiliye Belgeleri (C. DH.)

76-3780.

Bâb-ı Defterî Baş Muhasebe Bina Eminliği Defterleri (D. BŞM. BNE. d.) $16224 ; 16431$.

Bâb-1 Defterî Baş Muhasebe Muhallefat Defterleri (D. BŞM. MHF. d.) 
13237.

Dâhiliye Nezâreti Mektûbî Kalemi (DH. MKT.)

431-57; 1055-9.

Dâhiliye Nezareti Umûr-1 Mahalliye-i Vilâyât Müdürlüğü (DH. UMVM.)

97-38.

Hatt-1 Hümâyun Tasnifi (HAT.)

1224-47828.

İrade Dâhiliye (İ. DH.)

591-41111; 1454-17; 1454-1325.Ra/17.

İrade Hariciye (İ. HR.)

$2-51$.

İrade Meclis-i Vâlâ (İ. MVL.)

296-12002.

İrade Şûrâ-yı Devlet (İ. ŞD.)

1702-23.

Nüfus Defterleri (NFS. d.)

3230.

Maliye Nezareti Varidat Muhasebesi Temettuat Defterleri (ML. VRD. TMT. d.) 9665.

Yıldız Husûsî Marûzât (Y. A. HUS.)

$335-66$.

\section{Antalya Şer'iyye Sicil Defterleri}

Defter No: 1, 3, 5, 6, 19.

\section{Topkapı Sarayı Müzesi Arşivi}

TSMA. E. 9420-1. 


\section{Kaynak ve Araştırma Eserler}

Akarca, Aşkıdil, Yunan Arkeolojisinin Ana Çizgileri I Şehir ve Savunması, Türk Tarih Kurumu Basımevi, Ankara 1998.

Arseven, Celal Esad, "Kale", Sanat Ansiklopedisi, c. II (VII. Fasikül), Milli Eğitim Basımevi, İstanbul 1983, ss. 908-910.

Aydın, Mahir, Vidin Kalesi Tuna Boyundaki İnci, Ötüken Neşriyat, İstanbul 2015.

Baykara, Tuncer, Anadolu'nun Selçuklular Devrindeki Sosyal ve İktisadi Tarihi Üzerine Araştrmalar, Ege Üniversitesi Basımevi, İzmir 1990.

Bean, George E., Eski Çağ’da Güney Kiyzlar, çev. İnci Delemen-Sedef Çokay, Arion Yayınevi, İstanbul 1999.

Bennett, Matthew; Bradbury, Jim vd., Dünya Savaş Tarihi Ortaçağ, Teçhizat Savaş Yöntemleri Taktikler 500-1500, c. 1, çev. Özgür Kolçak, Timaş Yayınları, İstanbul 2011.

Boran, Ali; "Osmanlı Dönemi Kale Mimarisi", Osmanh Ansiklopedisi, c. 10, Yeni Türkiye Yayınları, Ankara 1999, ss. 347-361.

Cağlar, Burhan, İngiliz Said Paşa ve Günliü̆̈̈ (furnal), Arı Sanat Yayınevi, İstanbul 2010.

Danieloğlu, D. E., 1850 Yilinda Yapılan Bir Pamphylia Seyahati, çev. Ayşe Özil, Sunaİnan Kıraç Akdeniz Medeniyetleri Araştırma Enstitüsü Yayınları, İstanbul 2010.

Davis, E. J., Anadolu, 19. Yüzylla Karya, Frigya, Likya ve Psidya Antik Kentlerine Mapılan Bir Gezinin Öyküsü, çev. Funda Yılmaz, Arkeoloji Sanat Yayınları, İstanbul 2006.

Erten, Süleyman Fikri, Antalya Tarihi, Antalya 1948.

Ertuğ, Zeynep Tarım, “Tablhane”, Türkiye Diyanet Vakfi (TDV) İslam Ansiklopedisi, c. 39, Türkiye Diyanet Vakfi Yayınları, Ankara 2010, ss. 333-334.

Evliya Çelebi, Günümüz Türkçesiyle Evliyâ Çelebi Seyahatnamesi: Kütahya, Manisa, İzmir, Antalya, Karaman, Adana, Halep, Şam, Kudiis, Mekke, Medine, c. I, haz. Seyit Ali Kahraman, Yapı Kredi Yayınları, İstanbul 2011.

Eyice, Semavi, "Kale”, Türkiye Diyanet Vakfi (TDV) İslam Ansiklopedisi, c. 24, Türkiye 
Diyanet Vakfi Yayınları, Ankara 2001, ss. 234-242.

Fikri, Süleyman, Antalya Livası Tarihi, Matbaa-i Âmire, İstanbul 1338.

Hellenkemper, H; Hild, F. "Lykien und Pamphylien", Tabula Imperi Byzantini, 8 (2004), ss. 297-359.

İbn-i Battuta, İbn Battuta Seyahatnamesi, cilt: I, çev. Sait Aykut, Yapı Kredi Yayınları, İstanbul 2004.

Lanckoronski, von Karl Grafen, Pamphylia ve Pisidia Kentleri, c. I, çev. S. B. Gün, Suna-İnan Kıraç Akdeniz Araştırmaları Enstitüsü Yayınları, İstanbul 2004.

Moğol, Hasan, Haritalarla Antalya, Mehter Yayınları, Ankara 1997.

Kadriye Hüseyin, Mukaddes Ankara'dan Mektuplar, çev. Necmeddin Sahir Sılan, Cumhuriyet Kitap, İstanbul 1999.

Karaca, Behset, "XVI. Asırda Antalya Tersanesi ve Burada Gemi Yapımı", ed. B. Koçakoğlu, B. Karslı, Antalya Kitabı Selçukludan Cumhuriyet'e Sosyal Bilimlerde Antalya 1, Palet Yayınları, Konya 2018, ss. 78-95.

Keegan, John, Savaşs Sanat Tarihi, çev. Füsun Doruker, Yeni Yüzyıl Yayınları, İstanbul 1995.

Kırçınzade Süleyman Şükrü, Seyahatül-Kübra, yay. Salip Şapçı, Eğirdir Belediyesi, Eğirdir 2005.

Konya Vilayeti Salnamesi (KVS) Def'a 28, Konya 1317.

Konya Vilayeti Salnamesi (KVS) Def'a 30, Konya 1332.

Krickl, Ernst, 1892 Likya Günlïğü, çev. Filiz Dönmez Öztürk, Z. Zühre İlkgelen, Suna İnan Kıraç Akdeniz Araştırmaları Enstitüsü Yayınları, İstanbul 2005.

Le Bruyn, Corneille, Voyage au Levant, L'Asie Mineure, Chio, Rhodes, Chypre, E̋c. D’Egypte, Syrie, E' Terre-Sainte, c. II, Paris 1725.

Özaydın, Abdülkerim, "Nevbet", Türkiye Diyanet Vakfi (TDV) İslam Ansiklopedisi, c. 33, Türkiye Diyanet Vakfi, Ankara 2007, ss. 38-41.

Özdemir, Rıfat, "Osmanlı Döneminde Antalya'nın Fiziki ve Demografik Yapısı (1800-1867)", XI. Türk Tarih Kongresi (5-9 Eylïl), Kongreye Sunulan Bildiriler, c. IV, Türk Tarih Kurumu Yayınları, Ankara 1994, ss. 133-166. 
Pehlivanidis, Georgos, Attáleia kai Attaleiótes, Pamfylía, Lykía, Pisidia, Kilikia A, Atlantîs Yayınları, Athína 1989.

Pîrî Reis, Kitab-ı Bahriyye, ed. Bülent Özükan, Boyut Yayınları, İstanbul 2013.

Redford, Scott; Leiser, Gary, Taşa Yazılan Zafer Antalya İçkale Surlarndaki Selçuklu Fetihnamesi, çev. İnci Türkoğlu, Suna-İnan Kıraç Akdeniz Medeniyetleri Araştırma Enstitüsü Yayınları, İstanbul 2008.

Sevgen, Nazmi, Anadolu Kaleleri, Doğuş Matbaası, Ankara 1959.

Sperling, E. "Ein Ausflug in die Isaurischen Berge im Herbst 862", Zeitschrift für Allgemeine Erdkunde, c. 16, Berlin 1864, ss. 1-69.

Stein, Mark L. Osmanl Kaleleri Avrupa'da Hudut Boyları, çev. Gül Çağalı Güven, İş Bankası Yayınları, İstanbul 2007.

Şenyurt, Oya, "III. Selim Döneminde İnşaat Ortamını Yönlendiren İki Fransız Mühendis ve Kale Tamirleri”, Tarih Incelemeleri Dergisi, XXVIII/2, 2013, ss. 487-521.

Tızlak, Fahrettin, "Tekelioğlu İsyanı", XIII. Tarih Kongresi (4-8 Ekim), Kongreye Sunulan Bildiriler, c. III, Türk Tarih Kurumu Yayınları, Ankara 2002, ss. 237-254.

Yılmaz, Leyla, Antalya (16. Yüzynln Sonuna Kadar), Türk Tarih Kurumu Yayınları, Ankara 2002.

Yilmaz, Leyla-Tuzcu, Kemal, Antalya’da Türk Dönemi Kitabeleri, Haarlem 2010.

Yılmaz, İbrahim-Dikmen, Ümit, "Osmanlı Döneminde Kullanılan Yaklaşık Maliyet Tahmin Yöntemleri”, New World Sciences Academy, c. 7, no. 1, 2012, ss. 73-83

Varkıvanç, Burhan, "Surların Oluşum Süreci Üzerine Bazı Gözlemler”, içinde Redford, Scott; Leiser, Gary, Taşa Yazılan Zafer Antalya İckale Surlarndaki Selçuklu Fetihnamesi, çev. İnci Türkoğlu, Suna-İnan Kıraç Akdeniz Medeniyetleri Araştırma Enstitüsü Yayınları, İstanbul 2008.

Wilson, Charles, Handbook for Travellers in Asia Minor, Transcaucasia, Persia, etc., London 1895. 


\section{EKLER}

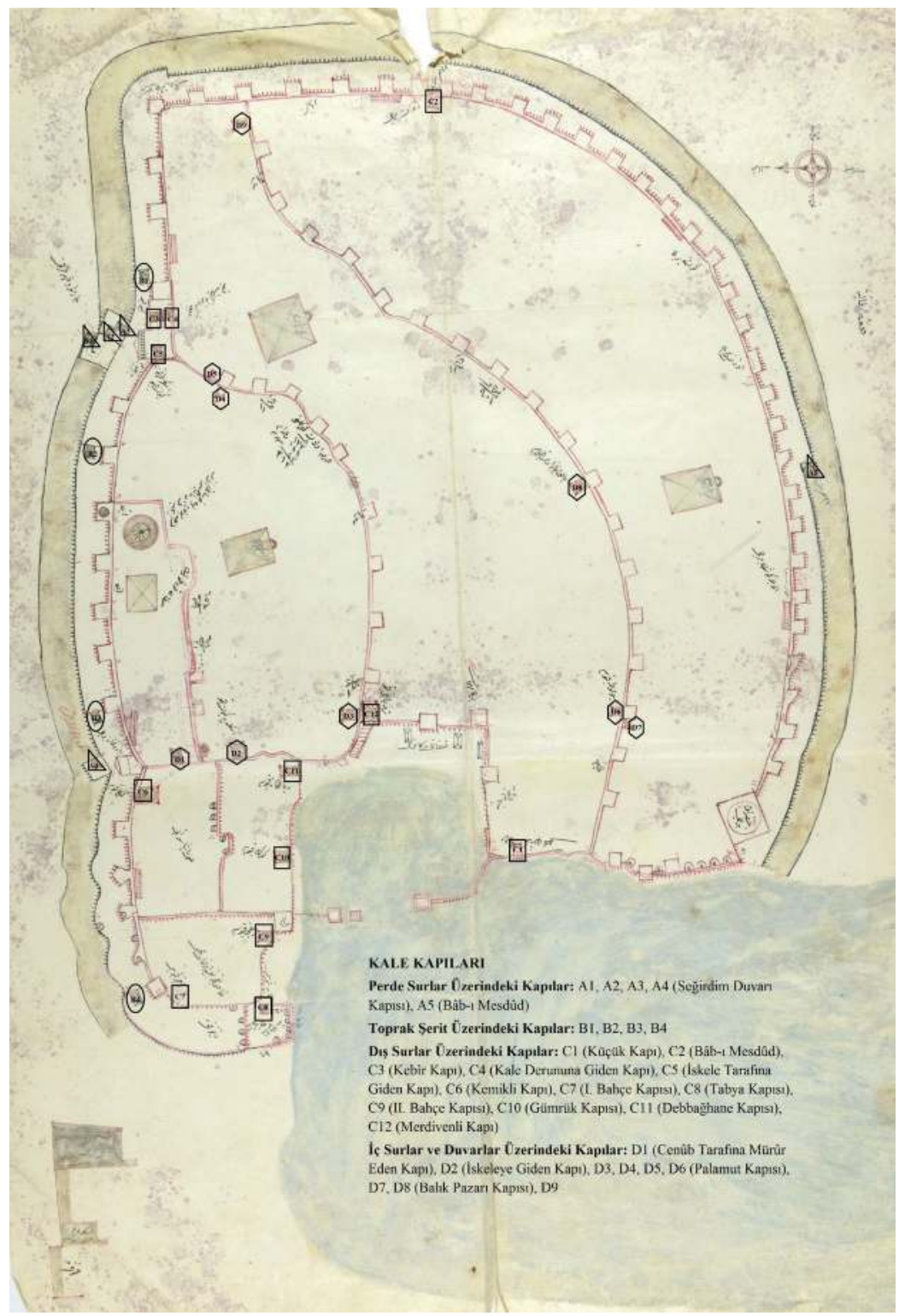

Ek 1: 1815 haritasında Antalya Kalesi'nin kapıları 


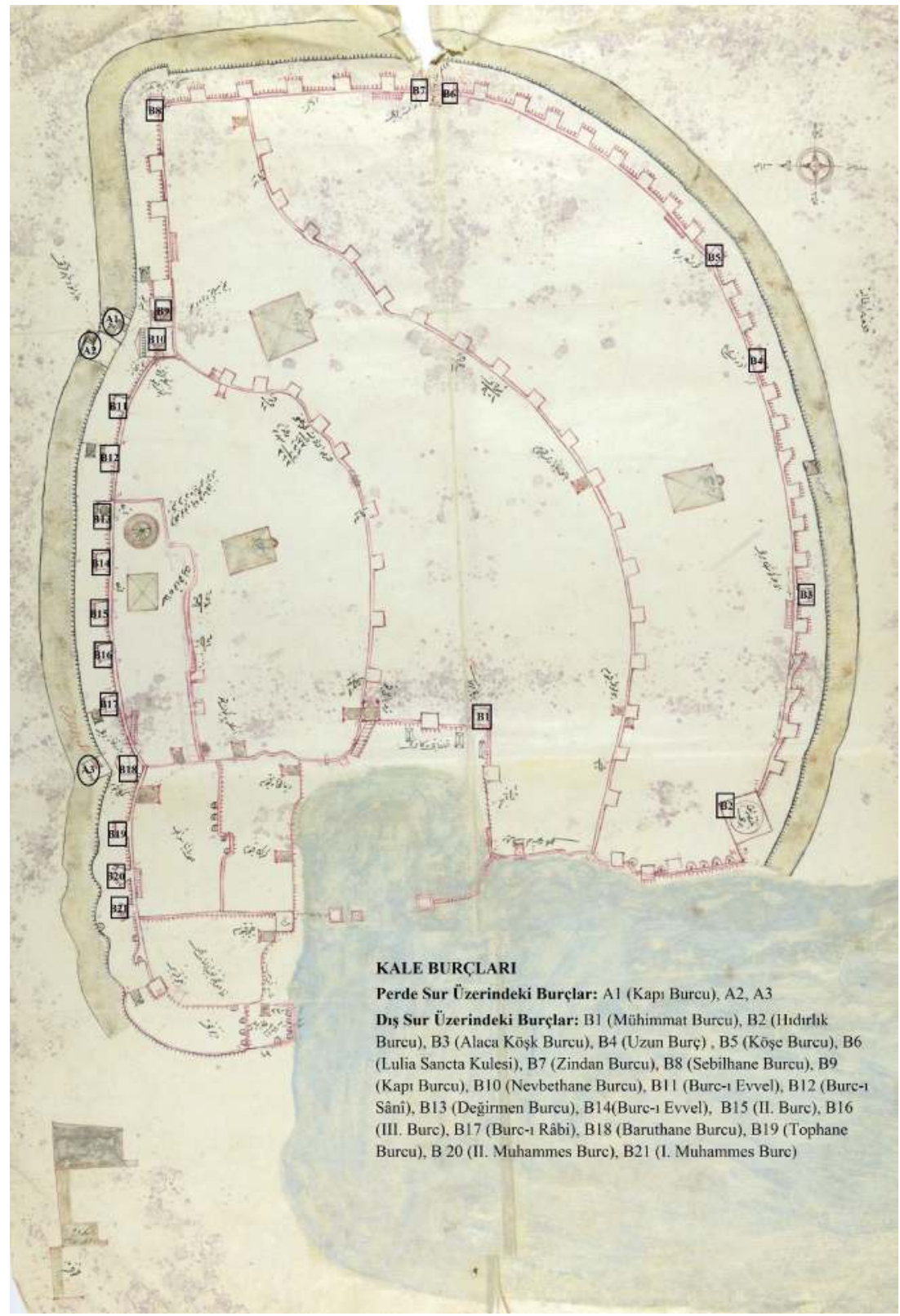

Ek 2: Antalya Kalesi'nin tanımlı burçları 


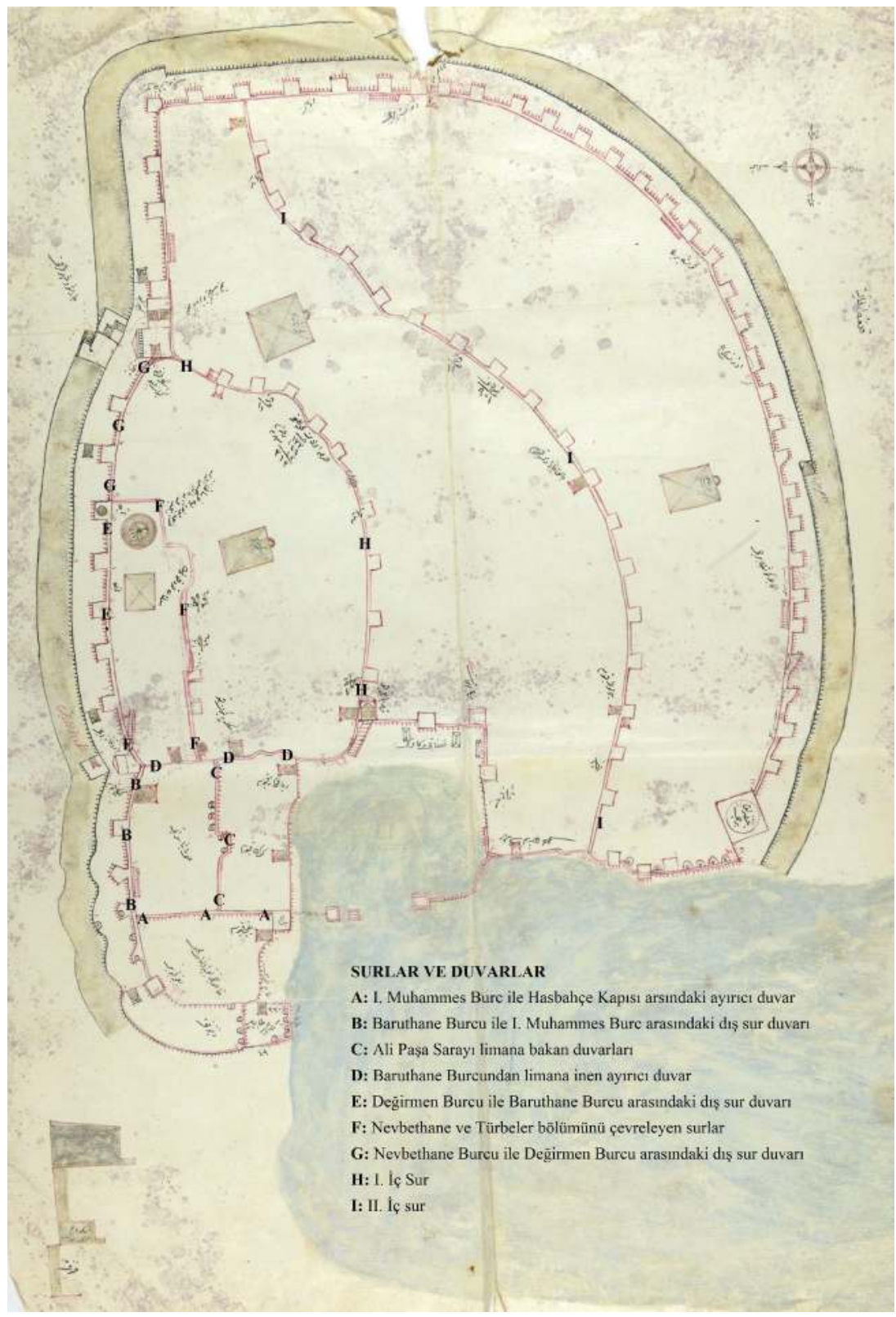

Ek 3: Antalya Kalesi'nin sur ve duvarları 


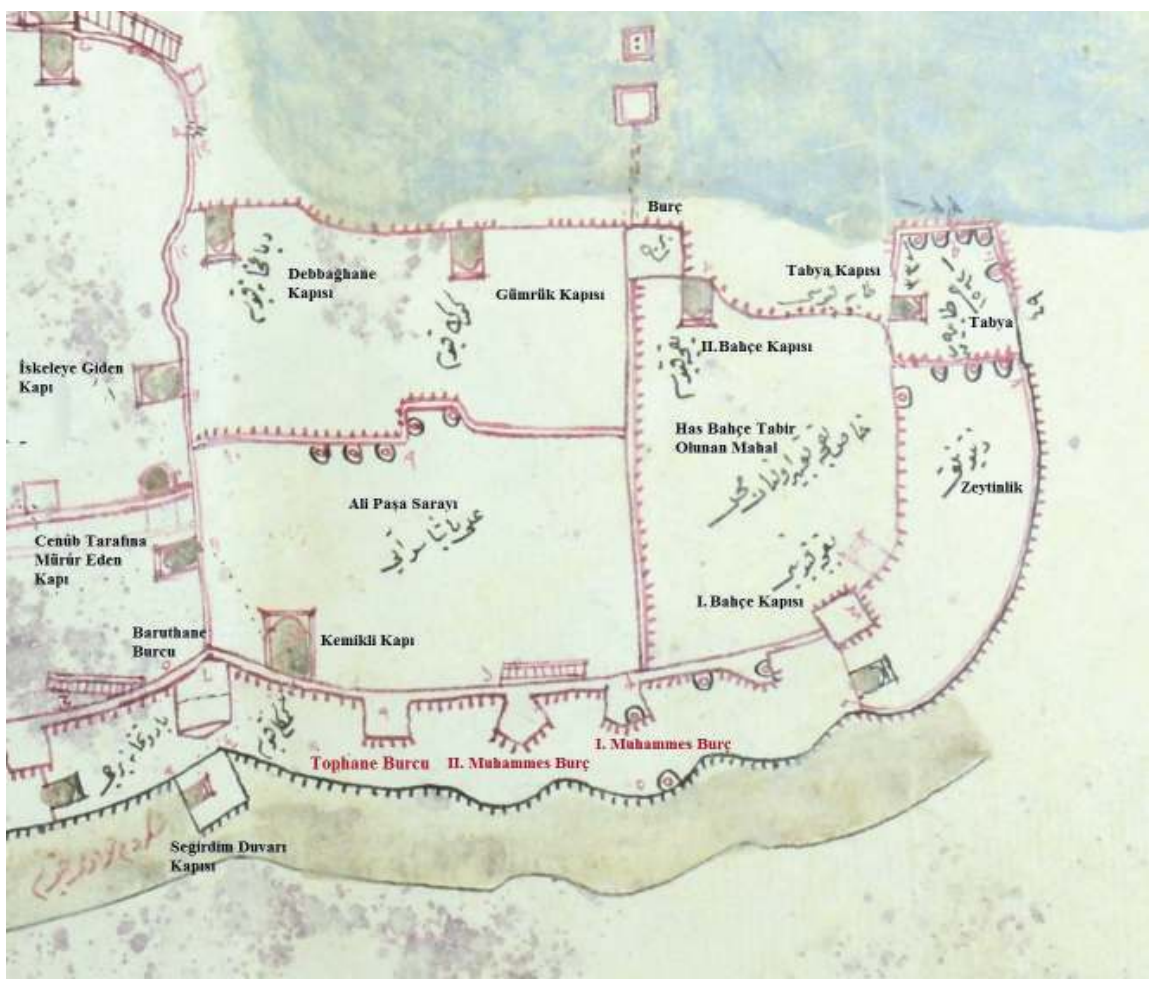

Ek 4: Ali Paşa Sarayı, Hasbahçe ve Gümrük 


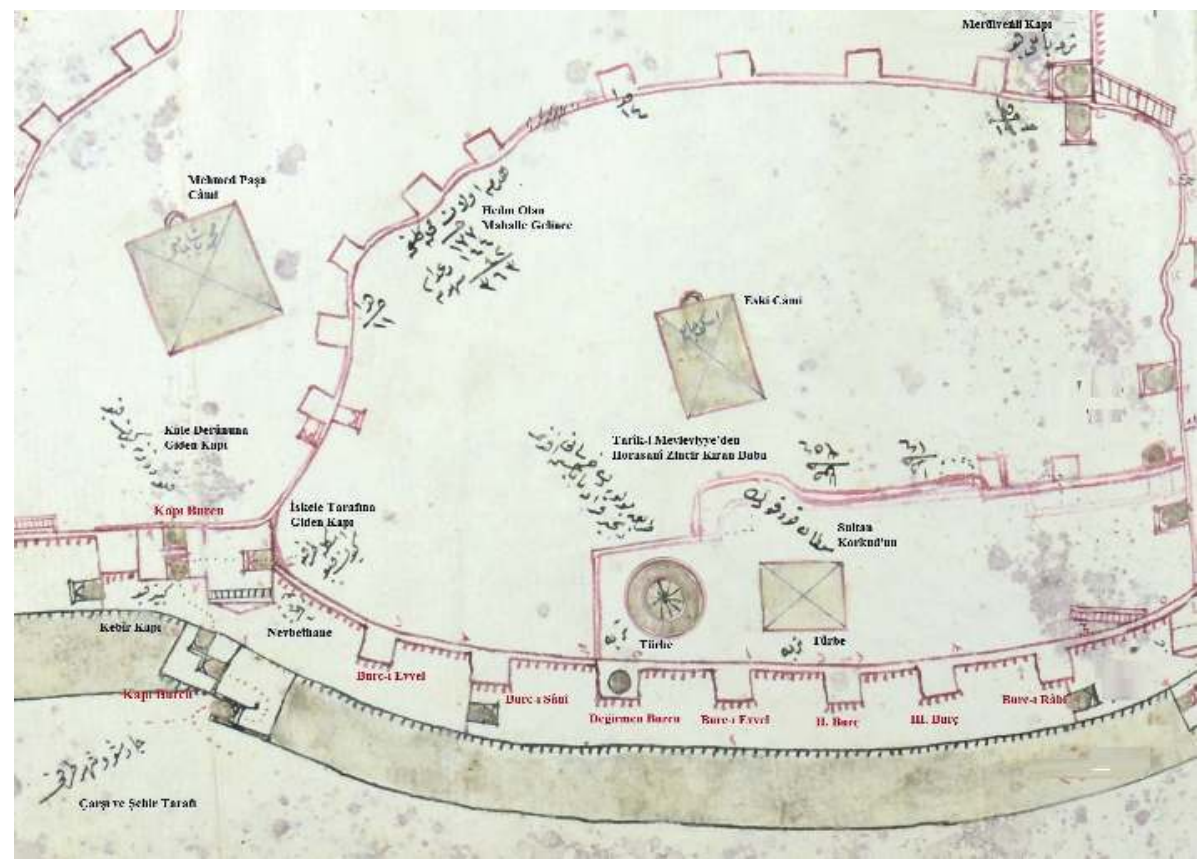

Ek 5: Kebîr Kapı, Câmi-i Atik Mahallesi ile Mevlevihane ve Türbeler Bölümü 


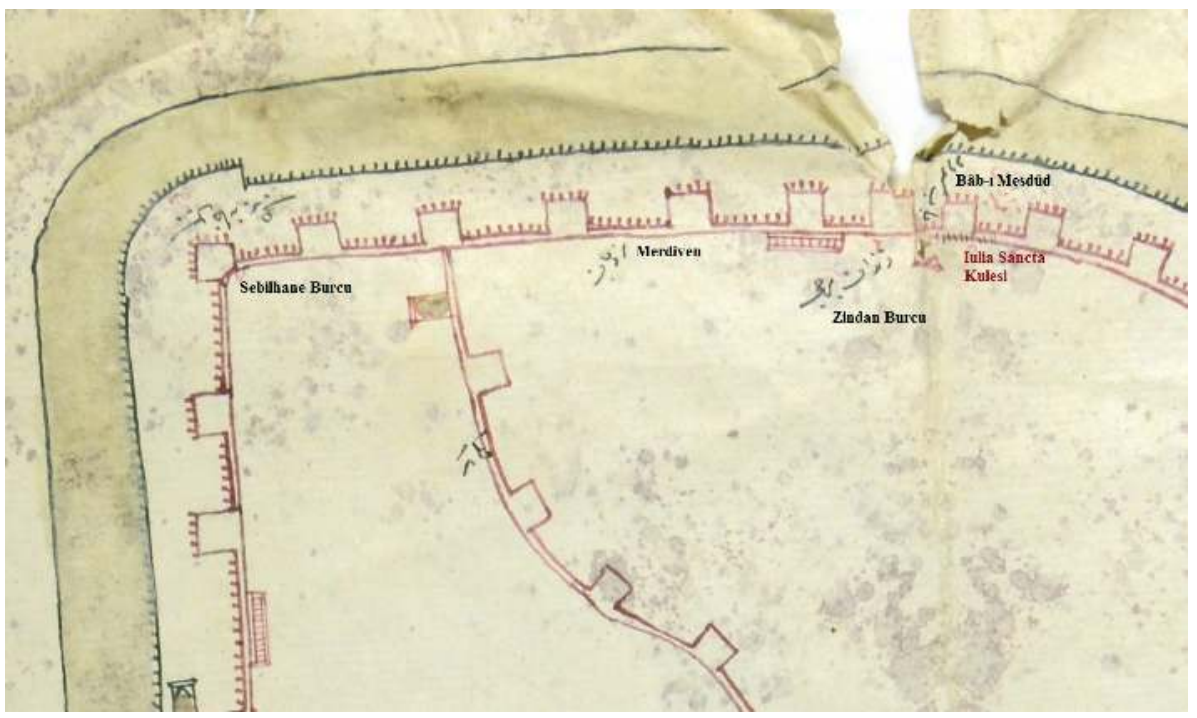

Ek 6: Sebilhane Burcu ve Bâb-1 Mesdûd

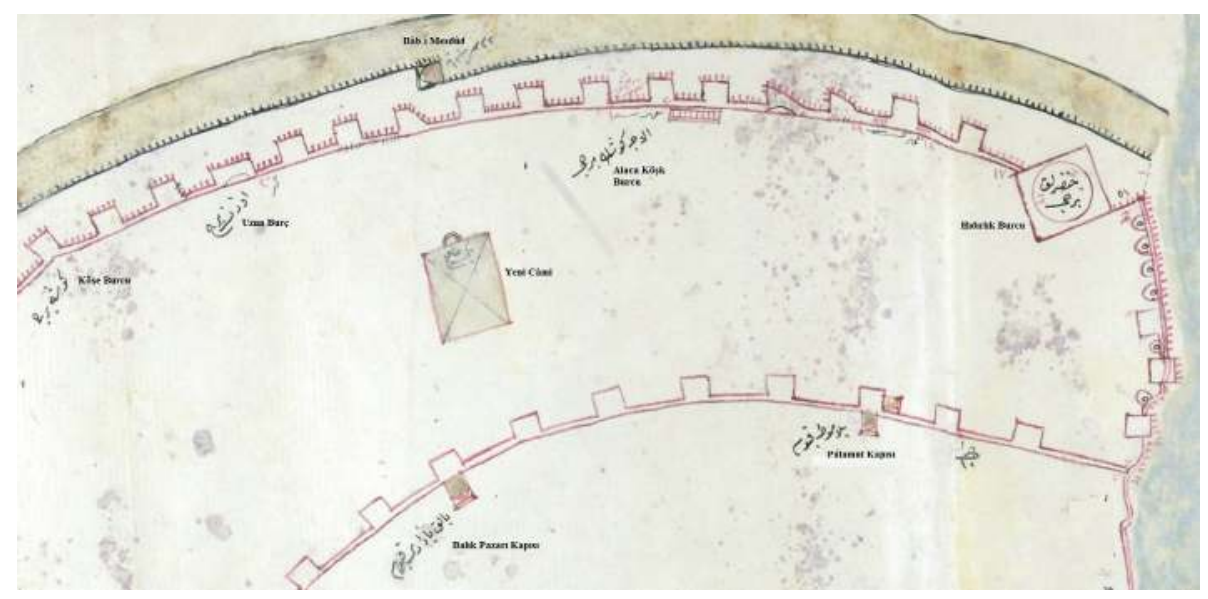

Ek 7: Hıdırlık Burcu ve Güney Kaleiçi 


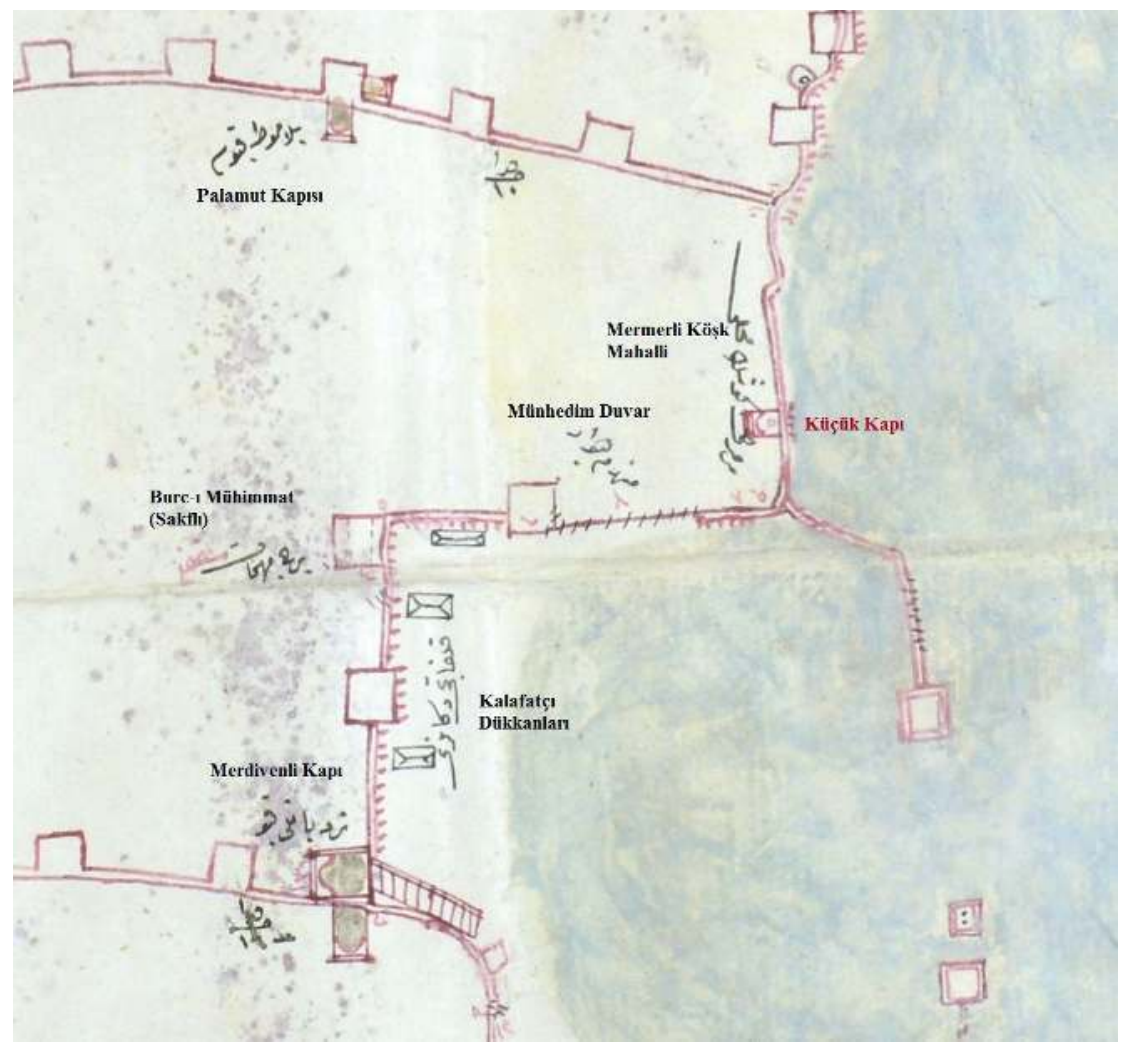

Ek 8: Mermerli ve Merdivenli İskele 


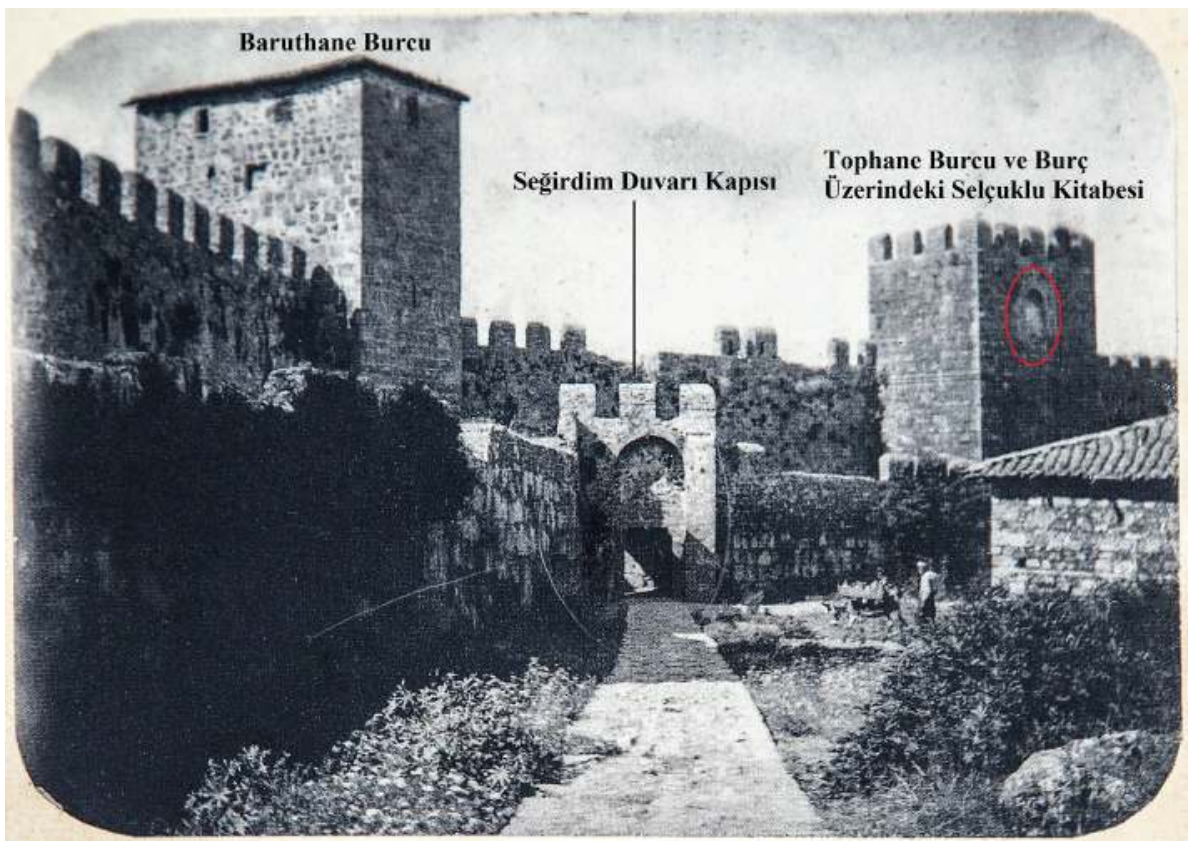

Ek 9: Çatılı Baruthane Burcu, perde sur üzerinde yer alan Seğirdim Duvarı Kapısı ve üzerinde Selçuklu kitabesi bulunan Tophane Burcu.

Kaynak: Ernst Krickl, 1892 Lykia Günlüğü, çev. Filiz Dönmez, Zühre İlkgelen, İstanbul 2005. 


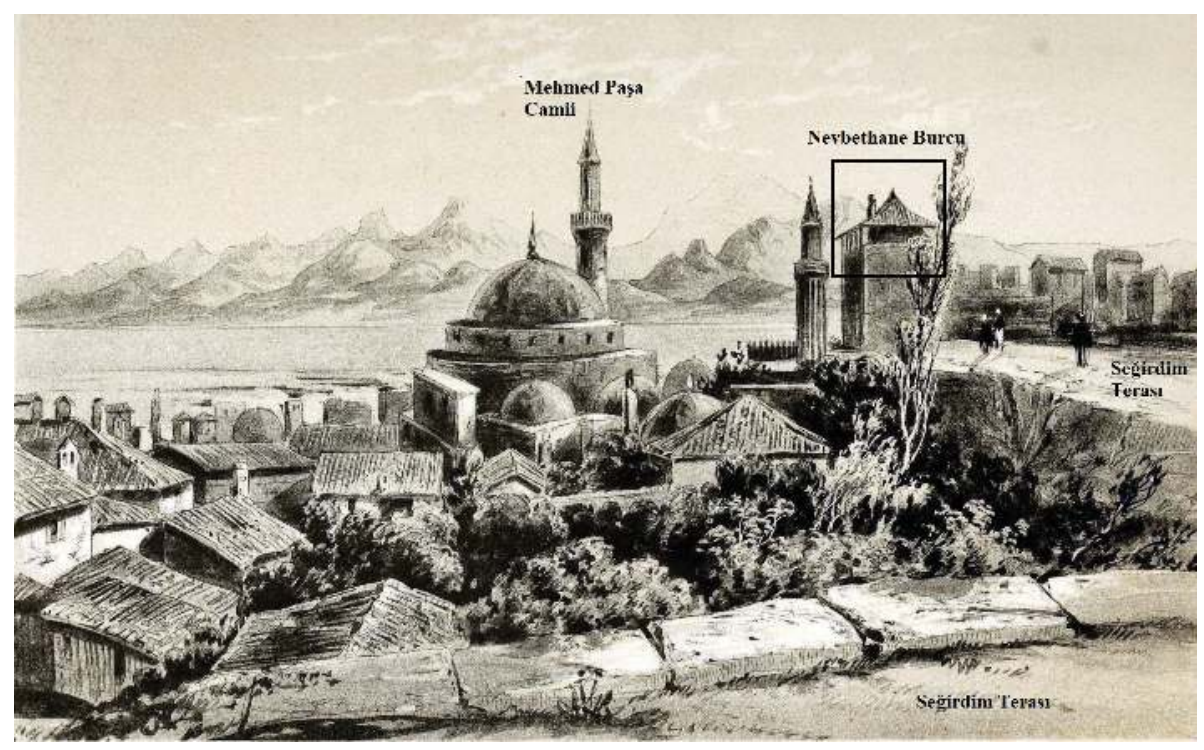

Ek 10: Nevbethane Burcu ve seğirdim terası.

Kaynak: Thomas A. B. Spratt - Edward Forbes, Travels in Lycia, Milyas, and the Cibyratis, Londra 1847. 


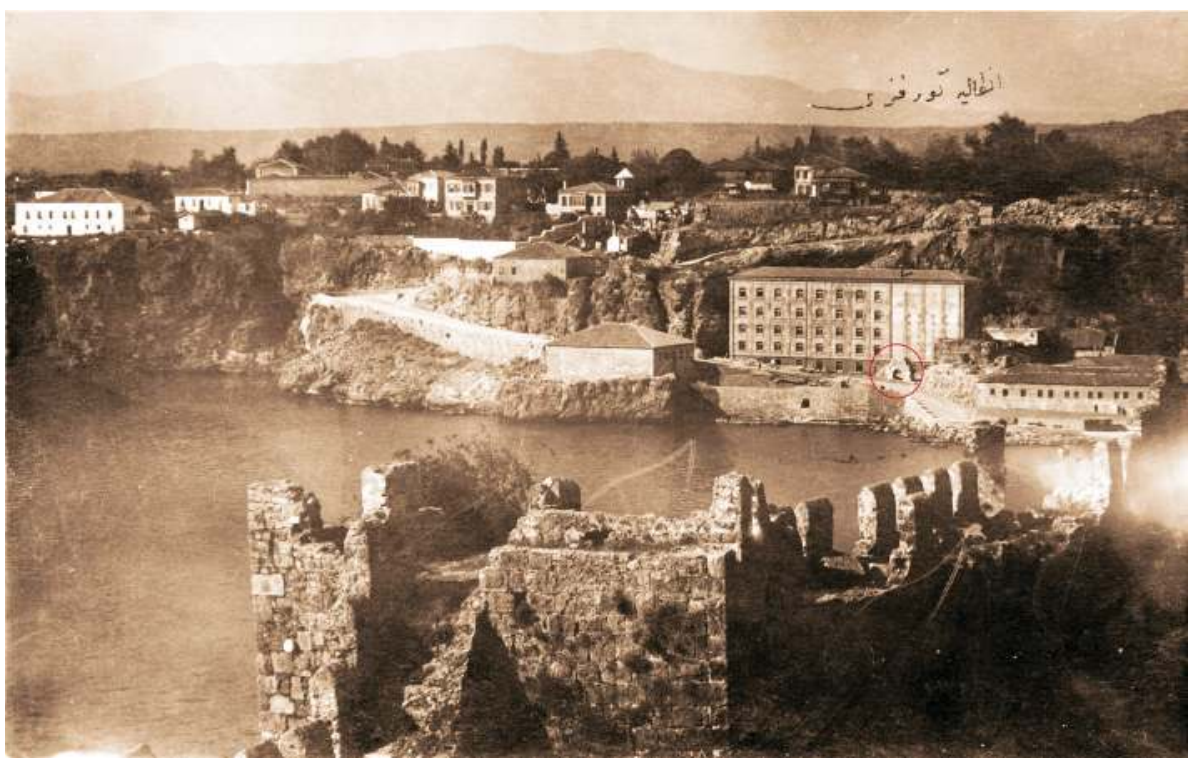

Ek 11: "Hasbahçe Kapısı" adıyla da bilinen II. Bahçe Kapısı'nın yıkıntıları.

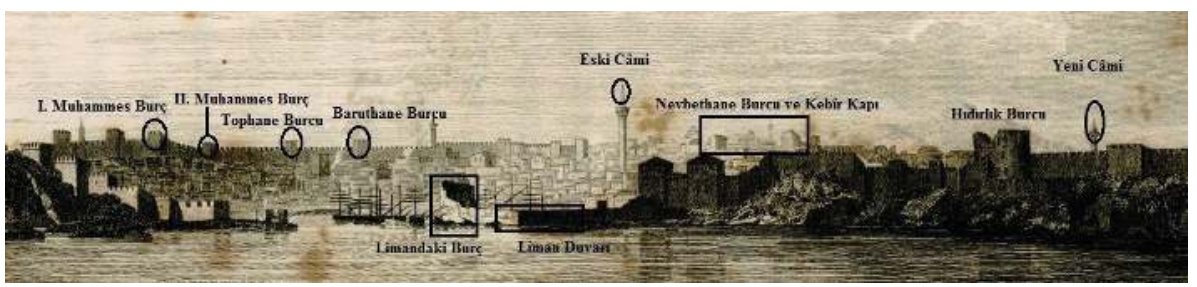

Ek 12: 1812 yılında G. Cooke tarafindan çizilmiş Antalya resmi.

Kaynak: Francis, Beaufort, Karamania, or a Brief Description of the South Coast of Asia Minor and of the Remains of Antiquity, Londra 1817.

Belleten, Ağustos 2020, Cilt: 84/Sayı: 300; 667-716 


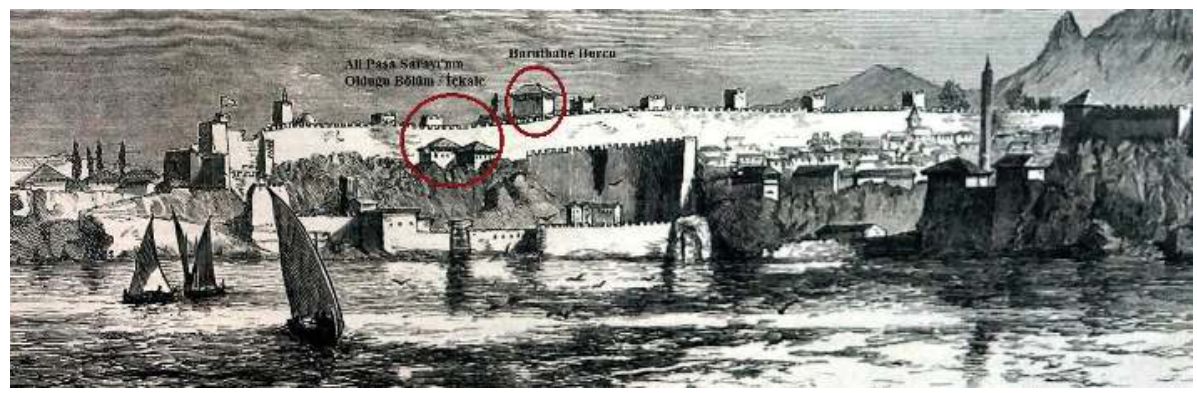

Ek 13: Baruthane Burcu ve Ali Paşa Sarayı'nın Olduğu Bölüm / İçkale.

Kaynak: The Graphic, 17 April 1880. 